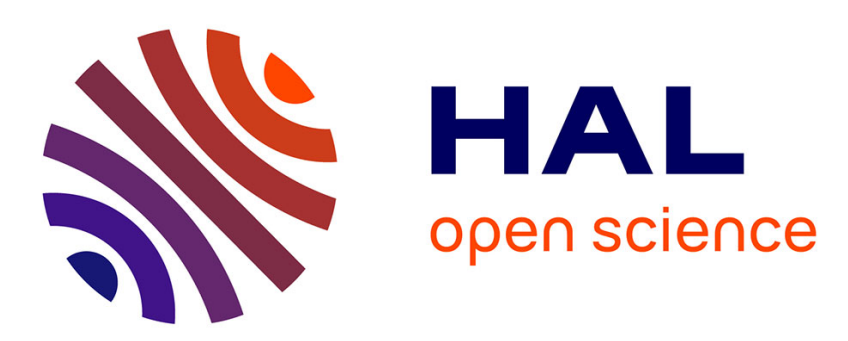

\title{
Physical and microstructural impacts on the hydro-mechanical behaviour of Ypresian clays
}

X.P. Nguyen, Yu-Jun Cui, Anh Minh A.M. Tang, X.L. Li, L. Wouters

\section{To cite this version:}

X.P. Nguyen, Yu-Jun Cui, Anh Minh A.M. Tang, X.L. Li, L. Wouters. Physical and microstructural impacts on the hydro-mechanical behaviour of Ypresian clays. Applied Clay Science, 2014, 102, pp.172-185. 10.1016/j.clay.2014.09.038 . hal-01119445

\section{HAL Id: hal-01119445 \\ https://hal-enpc.archives-ouvertes.fr/hal-01119445}

Submitted on 23 Feb 2015

HAL is a multi-disciplinary open access archive for the deposit and dissemination of scientific research documents, whether they are published or not. The documents may come from teaching and research institutions in France or abroad, or from public or private research centers.
L'archive ouverte pluridisciplinaire HAL, est destinée au dépôt et à la diffusion de documents scientifiques de niveau recherche, publiés ou non, émanant des établissements d'enseignement et de recherche français ou étrangers, des laboratoires publics ou privés. 


\section{Physical and microstructural impact on the hydro-mechanical behaviour of Ypresian clays

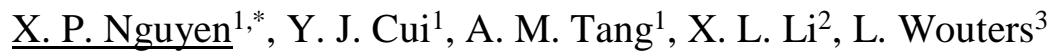

1. Laboratoire Navier (UMR 8205), CNRS, ENPC, IFSTTAR, Université Paris-Est, F-77455 Marne-la-Vallée, France (phunguyenx@gmail.com; yujun.cui @enpc.fr; anhminh.tang@enpc.fr)

2. ESV EURIDICE GIE, Boeretang 200, BE-2400, MOL, Belgium (xli@euridice.be)

3. ONDRAF/NIRAS, Avenue des Arts, BE-1210, Brussels, Belgium (1.wouters@nirond.be)

*. Presently at CEA, DEN, DPC, SECR, Laboratoire d'Étude du Comportement des Bétons et des Argiles, F-91191 Gif-sur-Yvette, France (1)

Corresponding author:

$$
\text { Dr Xuan Phu NGUYEN }
$$

CEA, DEN, DPC, SECR, LECBA

Bat. 133, P. 103F

F-91191 Gif-sur-Yvette

France

Telephone: +33169083348

Email:phunguyenx@gmail.com 
29 Abstract: An experimental characterisation on Ypresian clays that are considered as one of the potential geological host formations for the radioactive waste disposal in Belgium has been carried out. Physical, microstructural, hydraulic and mechanical properties were investigated on the samples taken from a cored borehole at Kallo in the Northern Belgium at $290-400 \mathrm{~m}$ depth. Identification tests, scanning electron microscopy (SEM), mercury intrusion porosimetry (MIP) and œdometer tests were performed. The results obtained showed that Ypresian clays are highly plastic and their physical and mineralogical properties present significant variations over depth. Compared to Boom Clay, the other potential host formation for the radioactive waste disposal in Belgium, Ypresian clays show (i) clearly higher liquid limit and specific surface, especially for its basal part ; (ii) lower density despite its deeper location; and (iii) lower degree of saturation of samples. These features were related to a bi-modal pore-size distribution which is quite particular for a sediment at such depth. Furthermore, it has been observed that the compressibility and swelling capacity of Ypresian clays increase with depth while the permeability decreases despite the increase in void ratio. The normalized compression curves confirm the soil compressibility variations over depth and the slightly over-consolidated state of Ypresian clays. 


\section{Introduction}

Ypresian clays, situated between 290 - 400 m depth at Kallo (Northern Belgium), are considered as a potential host formation in the Belgian high-level and/or long-lived (HL/LL) radioactive waste disposal program. As opposed to the situation of Boom Clay, another potential host formation which has been extensively investigated since the seventies in the laboratory and also in situ in the "High Activity Disposal Experimental Site" Underground Research Laboratory (HADES URL), the characterisation of Ypresian clays has been quite limited: before 1997, geotechnical data on Ypresian clays were scarce and scattered as only few boreholes reaching the bottom of the formation had been drilled by the Geological Survey of Belgium and other bodies for different purposes. The first investigation campaign on Ypresian clays in the framework of the research \& development programme of radioactive waste disposal was started in 1997 - 1998 with several cored boreholes at the Doel site, situated in the North of the Antwerp city. This campaign focused on the mineralogy, geochemistry, hydrology and physical properties (Van Marcke and Laenen, 2005). Several boreholes were drilled at Kallo in 2008 - 2009 (Cammaer et al., 2009), about $10 \mathrm{~km}$ to the south of Doel, enabling the geomechanical characterisation of the Ypresian clays.

In the present work, four cores of Ypresian clays taken at different depths from the ON-Kallo-1 borehole were characterised in terms of physical properties, microstructure features, hydraulic and mechanical behaviours. Moreover, by analysing and integrating the data of Ypresian clays gathered at Doel (see Van Marcke and Laenen, 2005), a complete description of the variations of Ypresian clays' physical and microstructural properties in the horizontal and vertical directions is given, the impact of these variations on the hydro-mechanical behaviour was also analysed. 


\section{Materials and experimental methods}

\subsection{Geological description}

The Ieper Group was deposited during the Ypresian period (55 - 49.6 million years ago) in the northwestern half of Belgium. It outcrops in the southern part of the depositional area, gently dips and thickens toward the Northeast (Figure 1). The group comprises three marine sediment formations, Kortrijk, Tielt and Gent, and corresponds roughly to London clay in Southeast London, the "argile des Flandres" and the "argile Plastique" in Northern France (Van Marcke and Laenen, 2005).

The term "Ypresian clays" refers to the sediments deposited during Early and Middle Ypresian times including the Kortrijk Formation (Members of Orchies, Roubaix and Aalbeke) and a part of the overlying Tielt Formation (Kortemark Member; Figure 2). At the Kallo site, Ypresian clays were found between 289 and 400 m below surface: the Kortemark Member between 289 303 m depth, Aalbeke Member 303 - 311 m, Roubaix Member 311 - 380 m and between 380 400 m depth the Orchies Member.

As Ypresian clays were deposited in a neritic environment in the southern border of the North Sea, their properties are significantly influenced by the transgressive - regressive cycles during their sedimentation: (i) the grading trend is fining-upward for transgression while coarseningupward for regression; and (ii) the clay-size mineralogy is composed of more kaolinite, illite and chlorite (non-expansive clay minerals) for transgression due to a distant detrital population source, but higher smectite for regression (Van Marcke and Laenen, 2005). The main transgressive - regressive cycles corresponding to the Ypresian clays' sedimentology at Kallo were estimated as shown in Figure 2 (Cammaer et al., 2009; Van Marcke and Laenen, 2005). Note that these main cycles can be further divided into several sub-cycles of higher resolution. 
The burial history of Ypresian clays at Doel shows several deposition - erosion cycles, resulting in a c.a. $50 \mathrm{~m}$ difference between the present depth and the maximum one in the history (Van Marcke and Laenen, 2005). Considering the vicinity between the Doel site and the Kallo site, we can consider that the two sites have a similar degree of over-consolidation.

It is noteworthy to distinguish the yield stress $\sigma_{y}^{\prime}$ from the pre-consolidation stress $\sigma_{p}^{\prime}$ (and thus, correspondingly, the yield stress ratio $Y S R=\sigma_{y}^{\prime} / \sigma_{v 0}^{\prime}$ from the over-consolidation one $O C R=$ $\sigma_{p}^{\prime} / \sigma_{v 0}^{\prime}$ ): (i) the latter results solely from mechanical unloadings, such as erosion or arising of water table (geological over-consolidation). It is estimated based on the maximal burial depth in the geological history; while (ii) the former involves, in addition, others geological phenomena, for example creep, digenesis, weathering, cambering and valley bulging.... It can be determined from œdometer test in the laboratory (Burland, 1990; Chandler, 2000). Naturally, $\sigma_{y} \geq \sigma_{p}$ and $Y S R \geq O C R$ (see Figure 16).

\subsection{Physical properties}

The four soil cores investigated in this study are from the borehole ON-Kallo-1 drilled by ONDRAF/NIRAS in 2008 - 2009 (Cammaer et al., 2009), and they are indicated in Figure 2: YK43 and YK64 are in the middle of the Roubaix Member, YK73 is in the lower part of the Roubaix Member and YK95 is taken in the upper part of the Orchies Member. Note that the soil cores were named by the initials of the formation and the site followed by its number in the borehole. For instance, YK43 means core number 43 of Ypresian clays from the borehole at Kallo. These cores were contained in PVC tubes of $96 \mathrm{~mm}$ in inner diameter and of $1 \mathrm{~m}$ in length, and wrapped in vacuumed aluminium foil. The two ends of each PVC tube were not 
sealed by wax; thus water loss would occur by evaporation before laboratory testing (2010 2011).

117 Figure 3 shows the particle-size distribution curves of the four adjacent cores (YK44, 63, 74 and

118 96) by laser technique (Vandenberghe, 2011). It appears that the clay-size $(<2 \mu \mathrm{m})$ fractions of

119 all cores are higher than $55 \%$. The Roubaix Member is known to be siltier (coarser) than the

120 Orchies (YK96) and Aalbeke Members, and this is clearly reflected in the granulometer curves.

121 The three Roubaix Member samples have a relatively similar granulometer distribution. It should

122 be noted that for a given soil, significant difference may exist between particle-size distribution

123 curves obtained by laser technique and by sieving and hydrometer, particularly for clayey soils

124 (Nguyen, 2013).

125 The mineralogical composition of the four previously mentionned cores by X-ray diffractometry 126 and cation exchange capacity (CEC) measurement (Co-hexamine technique) is presented in 127 Table 1 for the bulk mass and in

128 Table 2 for the clay-size fraction (Vandenberghe, 2011). It appears that the non-clay minerals 129 represent less than half in bulk mass, and the clay minerals are dominated by expansive ones 130 (smectite and interstratified illite - smectite) that represent more than $80 \%$ in clay-size $(>2 \mu \mathrm{m})$ 131 fraction and about two thirds in bulk mass. Moreover, the total clay minerals and the expansive 132 ones are quite similar for these four cores.

133 The physical and index properties of YK 43, 64, 73 and 95 are presented in Table 3 . The values 134 of Atterberg's limits of the Kallo samples (this study) together with those of Doel (Van Marcke 135 and Laenen, 2005) were used for establishing the classification of the Ypresian clays according 136 to ASTM (2006) (see Figure 4). It can be observed that the Ypresian clays are highly plastic at 
both the Kallo site and the Doel site. In particular, a liquid limit higher than 130 is identified on

138 YK73 and YK95. A large variability over depth of soils is also observed for both sites: YK73

139 (lower part of the Roubaix Member) and YK95 (upper part of the Orchies Member) have clearly

140 higher values of liquid limit and plasticity index than YK43 and YK64 (middle part of the

141 Roubaix Member). This is in agreement with the blue methylene value (VBS) determined

142 according to AFNOR (1998) and the specific surface $S_{s}$ deduced from VBS (Tran, 1980). A clear

143 distinction between these two groups of samples, (YK43, 64) and (YK73, 95), can also be

144 observed through other parameters presented in Table 3 such as unit mass $\rho_{0}$, dry unit mass $\rho_{d o}$,

145 void ratio $e_{0}$, porosity $n_{0}$ and water content $w_{0}$ : the two upper cores $(\mathrm{YK} 43,64)$ show higher $\rho_{0}$

146 and $\rho_{d 0}$ (lower $e_{0}, n_{0}$ and $w_{0}$ ) than the two lower ones (YK73, 95). The carbonate contents of

147 Ypresian clays are low, except for YK43 that has a particularly high value of $10.2 \mathrm{~g} / 100 \mathrm{~g}$. The

148 degree of saturation $S_{r 0}$ is lower than $100 \%$ for all samples, mainly owing to the water loss

149 during the sample conservation as stated above.

\subsection{Microstructural properties}

151 Figure 5 shows the Scanning Electron Microscope (SEM) photos of YK 43, 64, 73 and 95 on the

152 section perpendicular to the bedding plane. A dominance of silt grains with size up to $10 \mu \mathrm{m}$ are

153 identified for the two upper cores, especially for YK43. On the contrary, for the two lower cores,

154 a clay particle matrix is observed with dispersed silt grains. This is more or less consistent with

155 the grain-size distribution curves as shown in Figure 3: the fraction of particles larger than $10 \mu \mathrm{m}$

156 in (YK44, 63) is about $20 \%$, against only $15 \%$ and $5 \%$ in YK74 and YK96, respectively.

157 However, the important difference between YK74 and YK96 in grain-size distribution is not

158 observed in this SEM results. 
Figure 6 shows the pore-size distribution (PSD) curves of YK43, 73 and 95 by mercury intrusion porosimetry (MIP) in terms of intruded mercury void ratio $e_{m}$, defined as the ratio of mercury intrusion volume $V_{m}$ to soil solid volume $V_{s}$, versus the entrance diameter $D$ as well as $\delta e_{m} / \delta \log D$ versus $\log D$. It should be noted that the MIP technique used can only cover a range of pore sizes from $D=300$ to $0.005 \mu \mathrm{m}$, corresponding to a range of injection pressure from 0.1 to $200 \mathrm{MPa}$, and that the MIP tests on YK95 and YK43 were prematurely stopped due to a technical problem. It is observed that YK73 (lower part of the Roubaix Member) and perhaps YK95 (upper part of the Orchies Member) present bi-modal porosity with the density of the micro-pore family $(D=$ $0.06 \mu \mathrm{m}$ for YK73) clearly higher than that of the second family $(D=0.25 \mu \mathrm{m})$. The pore-size family around $D=100 \mu \mathrm{m}$ can be explained by the technical perturbation during the preparation of samples. By contrast, YK43 (middle part of the Roubaix Member) shows a mono-modal porosity with a sole dominant pore family of $D=0.8 \mu \mathrm{m}$. A macro-pore family at $D=5 \mu \mathrm{m}$ is identified for YK43 but its density is negligible. This mono-modal porosity is typical for deep sediments such as Boom Clay at Mol (Coll, 2005; Dehandschutter et al., 2004; Lima, 2011) and at Essen (Nguyen, 2013).

\subsection{Experimental methods for investigating the hydro-mechanical behaviour}

175 Both high- and low-pressure œdometers (HPO and LPO) were used. The LPO had only one lever

176 arm multiplying the load by 10 on the sample, allowing applying a vertical stress $\sigma_{v}$ up to 3.2

$177 \mathrm{MPa}$ on a sample of $50 \mathrm{~mm}$ diameter. The HPO had a double lever arm with one lever arm

178 multiplying the load by 5 and the other by 10, allowing applying a vertical stress $\sigma_{v}$ up to 64 179 MPa on a sample of $50 \mathrm{~mm}$ diameter. 
The soil samples were hand-trimmed to reach the dimensions of $50 \mathrm{~mm}$ in diameter and $20 \mathrm{~mm}$ in height. The initial states of the tested samples are shown in Table 4 with soil initial water content $w_{0}$, void ratio $e_{0}$, porosity $n_{0}$, degree of saturation $S_{r 0}$ and density $\rho_{0}$ as well as the void ratio under the in situ vertical effective stress, $e_{\sigma^{\prime} v}$. The HPO tests are numbered 1 while the LPO tests are numbered 2. In order to account for the deformability of the loading system in the HPO tests, calibration was carried out without sample in the œdometer cell following the same loading path as shown in Figure 7.

Typical test procedures for HPO and LPO tests are presented in Figure 7 and Figure 8, respectively. After installing the soil sample in the odometer cell, step loading (A - B) up to the in situ vertical effective stress $\sigma_{v 0}^{\prime}$, rounded for practical convenience to $3.2 \mathrm{MPa}$, was undertaken without putting the sample in contact with water in order to avoid soil swelling which would modify the soil microstructure (AFNOR, 1997; Delage et al., 2007; Deng et al., 2011a, $2011 b, 2011 c, 2012)$. Afterwards, the bottom porous stone and the drainage system were then filled with synthetic Ypresian clays water (SYCW) consisting of $8.896 \mathrm{~g} \mathrm{NaCl}$ and $0.896 \mathrm{~g}$ $\mathrm{Na}_{2} \mathrm{SO}_{4}$ in $1 \mathrm{~L}$ solution (Van Marcke, 2009). For HPO tests, two stepwise unloading - reloading loops between $\sigma_{v}=\sigma_{v 0}^{\prime}(\mathrm{C})-0.2(\mathrm{D})-16(\mathrm{E})-0.2(\mathrm{~F})-32(\mathrm{G}) \mathrm{MPa}$ and a final unloading from $\sigma_{v}=32 \mathrm{MPa}(\mathrm{G})$ to $0.2 \mathrm{MPa}(\mathrm{H})$ were then undertaken (Figure 7). For LPO tests, unloading from $\sigma_{v 0}^{\prime}$ to $0.05 \mathrm{MPa}(\mathrm{C}-\mathrm{D})$, reloading from $0.05 \mathrm{MPa}$ to $3.2 \mathrm{MPa}$ (D-E) and unloading again to 0.05 MPa (E-F) were conducted (Figure 8). The French standard (AFNOR, 1997) was applied for the volume change criterion: the volume change was considered as steady when the vertical strain rate was lower than $5 \times 10^{-4} / 8 \mathrm{~h}$. 


\section{Experimental results}

\subsection{Compressibility and swelling capacity}

203 Low- and high-pressure œdometer compression curves of YK43, 64, 73 and 95 are presented in 204 Figure 9, 10, 11 and 12, respectively. The values of degree of saturation $S_{r}$ during the initial loading (AB), before soaking (putting in contact with SYCW), were determined by assuming a constant water content $w=w_{0}$ and indicated on the curves. It appears that all soil samples reached full saturation at the end of this process, under $\sigma_{v}=\sigma_{v 0}=3.2 \mathrm{MPa}$, except the YK64O1 sample with a final value of $98 \%$ (Figure 10b). As all the curves are clearly non-linear, the compression index $C^{*}$ and swelling index $C^{*}{ }_{s}$ are adopted that correspond respectively to the 210 slopes of each (re)loading and unloading (Deng et al., 2011a). An increase of $C^{*}{ }_{c}$ when $S_{r}$ 211 approaches $100 \%$ is observed, especially for YK73 and 95. Le et al. (2011) conducted œdometer 212 tests on unsaturated Boom Clay samples with suction measurement and observed that this 213 increase in $C^{*}{ }_{c}$ corresponds to the suction becoming zero when pore water started to be squeezed 214 out.

215 Upon soaking, slight compressions are observed for all the tests. For YK64, 73 and 95, the void 216 ratios $e_{\sigma^{\prime} v 0}$ under the in situ vertical effective stress $\sigma_{v}=\sigma_{v 0}^{\prime}=3.2 \mathrm{MPa}$ (point C) in LPO and 217 HPO tests are almost the same (Table 4). On the contrary, for YK43, the value of $e_{\sigma^{\prime} v 0}$ in LPO 218 test (0.64) is smaller than that in HPO test (0.70). Note that the YK43 sample in LPO test has a 219 smaller initial void ratio $e_{0}$ than that in HPO test (0.78 against 0.81 ), but this difference is smaller 220 than that under the in situ stress (0.03 against 0.06$)$.

221 Upon the first unloading after soaking (C-D), two swelling fashions are identified: for YK43 and 22264 , the void ratio at the end of this unloading, under $\sigma_{v}=0.21 \mathrm{MPa}$ in HPO test and $0.05 \mathrm{MPa}$ in 223 LPO test (point D), is smaller than its initial value $e_{0}$, while for YK73 and 95 the inverse is 10 
observed, showing a higher swelling capacity than the two samples taken at upper depths. Note that the densities of YK73 and 95 samples at the beginning of this unloading under $\sigma_{v}=3.2 \mathrm{MPa}$ (point C) are lower than those of YK43 and 64 samples (see Table 4).

For all the four samples at different depths, the compression curves upon this unloading (C-D) are clearly non-linear as the swelling index $C^{*}{ }_{s}$ increases with the decrease of vertical stress $\sigma_{v}$. A roughly bi-linear shape was adopted by Cui et al. (2013) with a small slope $C_{\text {sel }}$ that corresponds to a mechanical rebounding under high vertical stress and a larger slope $C_{s p 1}$ that corresponds to a physico-chemical swelling under lower vertical stress, the two parts being separated by a swelling stress $\sigma_{s l}$ (Figure 13).

During the first reloading (D-E), the non-linearity of the curve was considered by Cui et al. (2013) as tri-linear: (i) when $\sigma_{v}<\sigma_{v 0}^{\prime}=3.2 \mathrm{MPa}$, the compression curve is bi-linear, formed by a small compression $\left(C_{c e l}\right)$ under low vertical stresses and a significant compression $\left(C_{c p l}\right)$ under higher vertical stresses; (ii) when $\sigma_{v}>\sigma_{v 0}^{\prime}=3.2 \mathrm{MPa}$, the compression curve progressively joins the virgin compression line defined by the common compression index $C_{c}$ (see Figure 13).

For each unloading - reloading loop, two swelling stresses $\sigma_{s}$ and four characteristic indices $C_{s e}$, $C_{s p}, C_{c e}, C_{c p}$ can be identified as illustrated in Figure 13. The yield stress $\sigma_{y}^{\prime}$ can be determined 240 according to the French standard (AFNOR, 1997) as the stress value corresponding to the intersection between the virgin compression line and the line passing by point C (in situ state) with the slope $C_{\text {sel }}$.

243 Figure 14 shows that the swelling stress $\sigma_{s}$ for each unloading/reloading path, in HPO and LPO 244 tests, is well correlated with the corresponding initial void ratio $e_{i}$ (the value before the unloading 245 or reloading). 
In addition, a series of swelling tests with "zero swell" method (Sridharan et al., 1986) was carried out by UCLouvain (1998) on Ypresian clays of several depths at the Doel site. Since the positions of Ypresian formation at Kallo (Cammaer et al., 2009) and Doel (Van Marcke \& Laenen, 2005) are different, "equivalent depth" was used to compare data of the two sites. Given $D_{K}$ a depth in Ypresian formation at Kallo, belonging to a member delimited by depth $H_{I K}$ on the top and depth $H_{2 K}$ at the bottom, and the corresponding limit depths of this member at Doel are $H_{I D}$ and $H_{2 D}$, the "equivalent depth" of $D_{K}$ at Doel $\left(D_{K D}\right)$ can be determined as follows:

$$
D_{K D}=\frac{D_{K}-H_{1 K}}{H_{2 K}-H_{1 K}} \times\left(H_{2 D}-H_{1 D}\right)+H_{1 D}
$$

The swelling stress $\sigma_{s}$ determined by "zero swell" method for the Ypresian clays at Doel at the equivalent depths, noted as YK43, 64, 73, 95-D, of the four studied cores are also presented in Figure 14 with the corresponding initial void ratio.

Linear relations between swelling stress $\sigma_{s}$ and corresponding initial void ratio $e_{i}$ are obtained in a semi-logarithmic plane for all the depths as observed by Cui et al. (2013). Moreover, good agreements between (i) Doel and Kallo sites (YK43 versus YK43-D and so on for YK64, 73 and 95), and (ii) common swelling tests and LPO and HPO compression tests are observed for each depth. For a given initial void ratio $e_{i}$, YK73 and YK95 (lower part of the Roubaix Member and upper part of the Orchies Member) show a significantly higher swelling stress $\sigma_{s}$ as compared to YK43 and 64 (the upper part of the Roubaix Member).

The variations of $C_{s e}$ and $C_{c e}, C_{s p}$ and $C_{c p}$ with the preconsolidation stress $\sigma_{p}$ for each unloading/reloading path are presented in Figure 15a and b, respectively. For the first unloading and reloading loop, as the soil is only slightly over-consolidated (see paragraph below), $\sigma_{p}$ was 
rounded to $\sigma_{v 0}^{\prime}=3.2 \mathrm{MPa}$ for simplicity. For the second and third unloading-reloading loops, based on the stress path in HPO tests, $\sigma_{p}^{\prime}$ was taken equal to 16 and $32 \mathrm{MPa}$, respectively. It appears that $C_{s e}$ and $C_{c e}$ are independent of the pre-consolidation stress $\sigma_{p}^{\prime}$ (Figure 15a) while $C_{s p}$ and $C_{c p}$ increase with the increase of $\sigma_{p}^{\prime}$. It is observed that these four indices are similar for YK43 and YK64. It is also the case for those of YK73 and YK95. $C_{s e}, C_{s p}$ and $C_{c p}$ of YK43 and YK64 are much smaller than those of YK73 and YK95, $C_{c e}$ being the same for the four samples. Furthermore, for YK43 and YK64, the differences between $C_{s e}$ and $C_{c e}$ and between $C_{s p}$ and $C_{c p}$ are not obvious. On the contrary, for YK73 and YK95, for a given $\sigma_{p}^{\prime}, C_{s e}>C_{c e}$ and $C_{s p}<C_{c p}$.

The variation over depth of compression index $C_{c}$ and yield stress $\sigma_{y}^{\prime}$ of Ypresian clays at Kallo, determined according to Figure 13, are presented in Figure 16. The yield stress ratio YSR and the over-consolidation ratio $O C R$ are also reported in this figure. It is observed that the compressibility of Ypresian clays increases with depth within the Roubaix Member (Figure 16a).

The yield stress $\sigma_{y}^{\prime}$ profile with indication of $Y S R$ and $O C R$ (Figure 16b) shows a good 280 correspondence between the geological study undertaken by Van Marcke \& Laenen (2005) and 281 this mechanical characterisation: the Ypresian clays are slightly over-consolidated and the YSR 282 for each depth is a little higher than the corresponding $O C R$. It also suggests that diagenesis as well as other geological events after deposition are of minor importance for the Ypresian clays. In addition, the long-term behaviour of the Ypresian clays was also investigated in this study through the secondary compression/swelling coefficient $C_{\alpha e}=-\Delta e / \Delta \log t$. Considering the 286 important role of the swelling stresses $\sigma_{s}$ on the compression curve e- $\log \sigma_{v}$, a correlation between $C_{\alpha e}$ with the ratio of vertical stress and swelling stress for the corresponding path $\sigma_{v} / \sigma_{s}$ 
definition, $C_{\alpha e}$ is positive upon (re)loading and negative during unloading (see Deng et al., 2012). It appears that for each depth a unique relationship $\left(C_{\alpha e}, \sigma_{v} / \sigma_{s}\right)$ can be adopted for 291 different reloading (or unloading) paths of both HPO and LPO tests as sketch in the Figure 17. 292 Similarity in $\left(C_{\alpha e}, \sigma_{v} / \sigma_{s}\right)$ between YK73 and 95 and between YK43 and 64 can be observed so as 293 only one trend line is adopted for the $C_{\alpha e}-\sigma_{v} / \sigma_{s}$ relation of each couple of cores in reloading (or 294 unloading). It is clearly observed that $C_{\alpha e}$ increases with the increase of $\sigma_{v} / \sigma_{s}$. Furthermore, for a 295 given $\sigma_{v} / \sigma_{s}$ ratio, YK73 and YK95 show higher $C_{\alpha e}$, in absolute value, than YK43 and YK64. 296 Taking into account the large lifespan of a radioactive waste disposal as well as significant 297 delayed convergence monitored in URL galleries (Armand et al., 2013), these simple and 298 efficient correlations would be of considerable interest for further investigation and modelling of 299 the long-term behaviour of the geological barriers in the performance assessment framework.

\subsection{Permeability}

301 Based on the consolidation curves, the hydraulic conductivity $k$ and permeability $K$ were 302 determined based on the Casagrande's method:

$$
k=\frac{C_{v} \rho_{f} g}{E_{\text {oed }}} \quad ; \quad K=\frac{k \mu_{f}}{\rho_{f} g}
$$

304 where $C_{v}=0.197 H^{2} / t_{50}$ is the consolidation coefficient, $H$ is the drainage length and $t_{50}$ is the 305 time corresponding to $50 \%$ consolidation degree; $\rho_{f}$ is the unit mass of fluid; $g$ is the acceleration 306 due to gravity; $E_{œ d}$ is the œdometric modulus; and $\mu_{f}$ is the fluid dynamic viscosity.

307 The variations of hydraulic conductivity $k$ and permeability $K$ with void ratio are presented in 308 Figure 18. It appears that for a given void ratio, the soil permeability decreases with depth within 
the range considered. In particular, the permeability of YK73 and 95 at their highest void ratio $(e$

$310 \approx 1)$ is still lower than that of YK43 at its lowest void ratio $(e \approx 0.5)$.

311 A series of permeability tests under isochore condition on Ypresian clays at Doel was conducted by Aertsens et al. (2005). The results are reported in Figure 19 for different depths. The values obtained in this study for the Kallo site are also presented in Figure 19 using the "equivalent depths" $D_{K D}$ (see Eq. (1)). It can be observed that the results of the two studies are comparable for the lower and the middle parts of the Roubaix Member. However, for YK43 the hydraulic conductivity found in this study is significantly higher than that from Aertsens et al. (2005). This shows some limitation of the comparison based on the notion of equivalent depth.

\subsection{Microstructure effect}

According to Mitchell \& Soga (2005), the soil microstructure is defined by particle arrangement and inter-particle bonding. Burland (1990) proposed a normalization method for the compression curve $e-\log \sigma_{v}$ which allows eliminating the effect of mineralogy and thus evidencing the effect of microstructure. As reconstituted clays have similar microstructure (Burland, 1990; Leroueil et al., 1985; Hong et al., 2010, 2012), their compression curves depend only on their mineralogy characterised by their plasticity. These curves can be normalized using the void index $I_{v}$ defined by:

$$
I_{v}=\frac{e-e_{100}^{*}}{e_{100}^{*}-e_{1000}^{*}}=\frac{e-e_{100}^{*}}{C_{c}^{*}}
$$

327 where $e_{100}^{*}$ and $e_{1000}^{*}$ are the void ratios at $\sigma_{v}^{\prime}=100$ and $1000 \mathrm{kPa}$, respectively; $C_{c}^{*}=e_{100}^{*}-e_{1000}^{*}$ is

328 the compression index. These parameters can be empirically determined using the void ratio $e_{L}$ at 329 liquid limit $w_{L}$ (Burland, 1990; Chandler, 2000). The asterisk denotes properties of soils at 
reconstituted state, considered as "intrinsic" and to be distinguished from the properties of soils at natural state that are affected not only by the mineralogy but also by microstructure.

By definition, all normalized compression curves $I_{v}-\log \sigma_{v}$ of reconstituted clays become a unique line passing by two points $(0 ; 100 \mathrm{kPa})$ and $(-1 ; 1000 \mathrm{kPa})$, namely intrinsic compression

334 line - ICL (Figure 20). For natural clays, due to their microstructure developed along their 335 geological history, their normalized compression curves lie on the right of ICL. Their positions 336 depend on their sensitivity $S_{\sigma}$ ranging generally from 1 for reconstituted soils to 10 (Cotecchia \& 337 Chandler, 2000). An average line at $S_{\sigma}=5$ was defined as sedimentation compression line (SCL) 338 by Burland (1990) and regarded as a typical relationship for marine sediments. Note that the 339 sedimentation compression curve (SCC) of a natural soil, which can only be determined from the 340 natural water content of undisturbed sample and thus cannot be reproduced in the laboratory, is 341 not necessarily the SCL, neither the normalized compression curve determined by œdometer test.

342 The normalized compression curves of Ypresian clays are presented in Figure 20. The star 343 symbols represent the in situ states. It appeared that differently from the in situ void ratio $e_{\sigma^{\prime} v 0}$, 344 the in situ void index $I_{v 0}$ decreases with depth, and thus better represents the deposition process 345 the deeper the soil, the lower its in situ void index. Similar remark was made by Skempton 346 (1970): the liquidity index $L I=(w-P L) /(L L-P L)$ is more representative of soil deposition 347 process than water content $w$.

348 A significant difference between the in situ states of YK43 and the three lower depths (YK64, $34973,95)$ can be observed: while $\left(I_{v 0}, \sigma_{v 0}^{\prime}\right)$ for YK43 is situated between the SCL and ICL with an 350 estimated SCC as indicated in Figure 20, the points $\left(I_{v 0}, \sigma_{v 0}\right)$ for (YK64, 73, 95) lie slightly 351 below the ICL. Their SCCs must then coincide with the ICL because all the SCC of natural soils 
must be on the right of the ICL or at least coincide with it. Due to these positions, the normalized compression curve of YK43 crosses its SCC before bending downward in parallel to the SCL and ICL, while the curves of (YK64, 73, 95) approach the ICL and then followed it. According to Baudet \& Stallebrass (2004), the parallelism between the virgin compression curves and the SCL and ICL suggests that Ypresian clays have stable structure, as opposed to the soils of metastable structure which have virgin compression slopes steeper than those of SCL and ICL.

\subsection{Microstructure after test}

MIP test was conducted on the sample after test YK73O1, corresponding to the state at point $\mathrm{H}$ in Figure 11b. The pore size distribution (PSD) curve for this sample is presented in Figure 21. The PSD curve of intact YK73 sample is also reported in this figure for reference. It appears that after the HPO test, the nearly bi-modal PSD curve becomes almost a mono-modal one with a dominant pore diameter around $D=0.3 \mu \mathrm{m}$. It is observed that the infra-pores (Romero, 1999)

364 with $D<0.02 \mu \mathrm{m}$ were not affected by the test, while meso-pores $(0.2<D<1 \mu \mathrm{m})$ increased in 365 detriment of the micro-pores $(0.02<D<0.2 \mu \mathrm{m})$ and the macro-pores $(D>1 \mu \mathrm{m})$. The pore366 size family around $D=100 \mu \mathrm{m}$ can also be explained by the technical perturbation during the 367 preparation of samples as for the intact sample.

368 The SEM photos on the sample after test YK43O2, corresponding to the state at point F in Figure 369 9a, are presented in Figure 22, together with those on the intact sample YK43. On the whole, the bonded structure of the intact sample becomes less bounded after the mechanical loading in saturated condition with well distinguished silt grains. 


\section{Discussion}

\subsection{Physical and microstructural properties}

The particle-size distribution (Figure 3) and mineralogical analyses (Table 1 and 2) by Vandenberghe (2011) showed that Ypresian clays are very fine-grained and highly plastic with significant amount of expansive minerals. These features are represented by their particularly high positions in the plasticity chart (Figure 4) and large values of initial void ratio $e_{0}$, specific surface $S_{s}$ and VBS (Table 3) identified in this study and by Van Marcke \& Laenen (2005). However there is a discrepancy between the results obtained by Vandenberghe (2011) and the results in the present study and Van Marcke \& Laenen (2005) in terms of variability of these properties. Indeed, according to Vandenberghe (2011), the differences in particle-size distribution and especially in mineralogical composition for the Ypresian clays at Kallo are not significant between the four depths. On the contrary, clear distinctions in terms of physical and index properties between the two groups of depths - group 1: the middle of the Roubaix Member (YK43 and YK64) and group 2: the lower part of the Roubaix Member (YK73) and the upper part of the Orchies Member (YK95) (Figure 2) - were identified in the two latter studies: the upper group (group 1) shows higher density but lower grain density $\rho_{s}$, consistence indices $L L$ and $P I$, specific surface $S_{s}$, blue methylene value $V B S$ and water content $w_{0}$ than the lower group ( group 2). Furthermore, these variations of $\rho_{s}, L L, P I, V B S, S_{s}$ and $w_{0}$ are better in line with the geological history of Ypresian clays that is characterised by several transgressive - regressive cycles (see section 2.1). Further studies on the particle size distribution and mineralogy of Ypresian clays at Kallo are needed to clarify this point.

The SEM observations (Figure 5) also confirms the large difference between these two groups: the microstructure of the lower group is dominated by clay particles with matrix type, while that 
of the upper group shows the dominance of silt grains with aggregate type. A progressive transition from the upper group to the lower one can be observed: the presence of clay fraction in YK64 is more obvious than in YK43 but still less than in YK73. Note that the carbonate content in YK43 $(10 \mathrm{~g} / 100 \mathrm{~g})$ is particularly higher than those in the three other depths. On the other hand, the PSDs of YK73 and probably YK95 (the lower group), show bi-modality with a dominant micro-pore family $(D=0.06 \mu \mathrm{m})$ at the intra-particle level and another dominant meso-pore family $(D=0.25 \mu \mathrm{m})$ at the inter-particle level; the PSD of YK43 is mono-modal with a sole dominant family of inter-particle pores having diameters as large as $D=0.8 \mu \mathrm{m}$. These microstructural differences are in good agreement with the macroscopic observations: the 404 initial void ratio $e_{0}$ of the upper group are lower than those of the lower one that has higher 405 plasticity.

\subsection{Hydro-mechanical behaviour}

407 The results of odometer tests of Ypresian clays with unloading - reloading cycles are 408 characterised by clear hysteresis. According to Cui et al. (2013) and Nguyen (2013), these 409 hysteretic loops can be explained by the competition between physico-chemical and mechanical 410 effects that are separated by a threshold stress $\sigma_{s}$ corresponding to the swelling stress. Note that 411 the term "mechanical" refers to the particle interactions through their direct contact, while the 412 term "physico-chemical" denotes the interactions between adsorbed water and clay particles. 413 Upon unloading, when the applied external stress is higher than the swelling stress $\left(\sigma_{v}>\sigma_{s}\right)$, or 414 at the microscopic level the effect of the applied stress is stronger than that of the repulsive force 415 between clay particles/sheets, the particles contact mode would be rather of face-to-face. As a 416 result, the volumetric behaviour is rather controlled by the mechanical effect and small elastic 417 rebound occurs. On the contrary, when $\sigma_{v}<\sigma_{s}$, the physico-chemical effect prevails as particles 19 
contact turns progressively into face-to-edge mode, giving rise to soil swelling with significant volume change. Upon reloading, when the applied stress is lower than the swelling stress for this path $\sigma_{v}<\sigma_{s}$, the face-to-edge particles contact microstructure is more or less preserved due to 421 the matrix suction caused by the physico-chemical effect, and small volume change occurs. By 422 contrast, when $\sigma_{v}>\sigma_{s}$, the mechanical effect prevails and larger volume change occurs by collapse of large-pores, re-orienting particles contact to be more and more face-to-face mode. Beyond the preconsolidation stress $\sigma_{v}>\sigma_{p}^{\prime}$, the plastic volume change makes the particle reorientation more significant. Therefore, unloading from a higher preconsolidation stress $\sigma_{p}^{\prime}$ 426 induces higher swelling slope $C_{s p}$ (see Figure 15b).

\subsubsection{Swelling capacity}

The higher positions of the $\log \sigma_{s}-e_{i}$ curves of YK73 and YK95 with respect to those of YK43 and YK64 in Figure 14 clearly distinguish the two groups in terms of swelling stress $\sigma_{s}$. In addition, a unique correlation between $e_{i}$ and $\sigma_{s}$ may be expected with normalization by 431 mineralogy, like the normalisation by dry density of bentonite in the case of bentonite mixtures 432 (Agus, 2005; Dixon et al., 1996; Lee et al., 1999; Wang et al., 2012). Unfortunately, the 433 discrepancy in mineralogical composition (Vandenberghe, 2011) and physical properties 434 mentioned above does not allow this normalisation in the present study.

435 The increase of the swelling slope $C_{s p}$ with the preconsolidation stress $\sigma_{p}^{\prime}$ 436 (see Figure 15) confirms the enhanced physico-chemical effect by mechanical loading (Le et al., 437 2011): the larger the virgin compression, the more the orientation of clay particles (face-to-face 438 particles contact mode) and thus the stronger the physico-chemical interaction between clay 
particles and adsorbed water. The following equation can be proposed to describe the increase of $C_{s p}$ with $\sigma_{p}^{\prime}$ :

$$
C_{s p\left(\sigma_{p}^{\prime}\right)}=\frac{C_{c}}{1+\left(\frac{C_{c}}{C_{s p 1}}-1\right) \times \exp ^{-\beta \ln \frac{\sigma_{p}^{\prime}}{\sigma_{p 1}^{\prime}}}}
$$

where $\beta$ is a parameter which controls the increase rate of $C_{s p}$ with $\sigma_{p}^{\prime}$. For YK43, 64, 73 and 95, $\beta=0.22,0.42,0.35$ and 0.35 , respectively; $\sigma_{p 1}(=3.25 \mathrm{MPa}$ in this study) is a reference stress corresponding to $C_{s p}=C_{s p 1}$. The Eq. (4)-based correlations are shown by dotted lines in Figure 15b. It is observed that the values of $C_{s e}$ and $C_{s p}$ as well as the slopes $\Delta C_{s p} / \Delta \sigma_{p}$ of the two lower depths (YK73 and 95) are larger than those of the two upper depths (YK43 and 64), despite the lower densities of YK73 and 95. This again confirms the higher swelling capacity of YK73 and 95.

The independence of $C_{s e}$ with respect to $\sigma_{p}^{\prime}$ confirms that the soil behaviour during unloading under $\sigma_{v}>\sigma_{s}$ is not significantly affected by the physico-chemical swelling, but characterised by the mechanical rebounding. This justifies the yield stress $\sigma_{y}^{\prime}$ determination method adopted in this study, avoiding inappropriate low values of $\sigma_{y}^{\prime}$ for deep sediments such as Boom Clay (Baldi et al., 1991; Deng et al., 2011b; Sultan et al., 2010) and London clay (Gasparre, 2005). Indeed, the values of $\sigma_{y}^{\prime}$ obtained in this study are in good agreement with the geological history characterised by the values of $O C R$. The slightly higher values of $Y S R$ with respect to $O C R$ can reasonably be related to the creep effect developed during the geological history of several millions of years. The larger difference between $Y S R$ and $O C R$ for YK73 (1.6/1.1) and 95 (1.4/1.1) compared to those for YK43 (1.2/1.1) and 64 (1.5/1.2) (Figure 16b) indicates that creep 
459 effect is more significant for the two lower cores than for the two upper ones. This is also 460 consistent with the higher swelling clay fraction of YK73 and YK95.

\subsubsection{Compressibility}

462 It is observed in Figure 15a that $C_{c e}$ is independent of $\sigma_{p}^{\prime}$ and the mineralogy as the values are 463 quite similar for the four depths. This suggests that the microstructure characterised by the face464 to-edge particles contact mode that developed during the previous unloading was almost 465 preserved when $\sigma_{v}<\sigma_{s}$. This suggests also that the macroscopic volume change resulted mainly 466 from the compression of clay particles. Due to the competition between the increasing external 467 applied stress $\sigma_{v}$ which tends to expel water from the clay particles and the physico-chemical interaction between clay sheet and pore water which generates matrix suction retaining pore water. The volume change in this stress range is thus negligible with $C_{c e}=0.02$.

When the external applied stress is beyond the swelling stress $\sigma_{v}>\sigma_{s}$, the mechanical effect 471 prevails causing macro-pore collapse, giving rise to larger volume change with $C_{c p}$. Note that the clay particle re-orientation in this stress range $\sigma_{s}<\sigma_{v}<\sigma_{p}^{\prime}$ is less marked than in the virgin compression domain where $\sigma_{v}>\sigma_{p .}^{\prime}$. Obviously, $C_{c p}$ also increases with $\sigma_{p}^{\prime}$ and clay fraction as 474 observed in Figure 15. Moreover, the variation of $C_{c p}$ must be limited by $C_{c}$ on the upper side 475 and by $C_{s e}$ on the lower side because for a given $\sigma_{p}^{\prime}$ the higher the vertical stress $\sigma_{v i}$ from which the reloading is initiated, the lower the corresponding $C_{c p}$.

477 The increases of $C_{c}$ (Figure 16a) and $C_{\alpha e}$ (Figure 17) with depth confirm the vertical variation of 478 the plasticity of Ypresian clays: the larger the consistence indices the larger the virgin and 479 secondary compression indices. This is in agreement with several correlations between 480 compression index and Atterberg limits in the literature for remoulded soils (Carrier, 1985; 

natural clayey soils (Johnson \& Moston, 1970).

\subsubsection{Permeability}

484

The permeability evolution of Ypresian clays at the Kallo site with depth is also in agreement with the variations of soil mineralogy, grain-size distribution and microstructure: despite their higher void ratios, YK73 and 95 show significantly lower permeability than YK43 and 64. This can be explained by two reasons. From a microstructure point of view, the aggregate type fabric and the dominance of macro-pores in YK43 and 64 form larger flow channel than the matrix type fabric and the dominance of micro-pores in YK73 and 95 (Figure 6). From a mineralogical point of view, water molecules in clay particles are associated with the exchangeable cations adsorbed on the clay sheets forming the diffuse double layer. This affects the mobility of water molecules and thus the permeability. Indeed, YK43 and 64 have similar void ratio (Table 4) and microstructure type (Figure 5), but YK64 clearly shows lower permeability (Figure 18) because of its higher plasticity index (Figure 4).

\subsection{Microstructure effect on volumetric behaviour}

The significantly higher positions of the in situ state $\left(I_{v 0}, \sigma_{v 0}\right)$ and the normalized compression curve of YK43 with respect to those of YK64, 73 and 95 in the $I_{v}-\log \sigma_{v}$ plane can be related to its lower clay fraction as observed on the SEM photos (Figure 5) and in the plasticity chart (Figure 4), and its higher carbonate content (Table 3) which plays a decisive role in inter-particle bonding. With the highest plasticity index and the lowest carbonate content, the normalized compression curve of YK73 is logically the lowest one. The curve of YK95 is close to that of 
YK73 albeit its higher carbonate content (3.8 against $0.9 \mathrm{~g} / 100 \mathrm{~g}$ ). This suggests that the effect of carbonates in the microstructure can be compensated by that of expansive clay minerals.

According to Burland (1990), the stable microstructure of Ypresian clays (virgin compression curves have the same slope as the SCL and ICL) indicates a quick deposition from a dense suspension and/or under strong current. These depositional conditions would give rise to a more oriented fabric thus more compact with a low void index $I_{v}$ (not necessarily low void ratio $e$ ).

Particularly high expansive mineral content could also be the reason for the evolution of the PSD curve, from nearly bi-modal for intact YK73 sample to nearly mono-modal for the sample after the HPO test (Figure 21). Indeed, under compression at high pressures, clay particles were reoriented and fill the meso- and macro-pores. The porosity under high pressures became more and more homogeneous with a sole dominant micro-pores. Upon unloading, due to the effect of expansive minerals, the uniformity of the porosity was preserved as the dominant micro-pore family swelled homogeneously to reach the size of meso-pores. On the contrary, due to the limited amount of clay minerals, after the LPO test, the aggregate type microstructure of YK43 became even clearer as clay particles were only able to coat the silt grains, but not enough to form a matrix. Therefore, the swelling upon unloading from $\sigma_{v}=\sigma_{v 0}^{\prime}$ consisted mainly in the rebounding of the "frame structure" built by clay-coated silt grains, which is different from the volume change mode of YK73. Thus, the void ratios at the end of the first unloading (point D) in both LPO and HPO tests are much lower than the initial value $e_{D}<e_{0}$ for YK43 (Figure 9), but higher than the initial value $e_{D}>e_{0}$ for YK73 (Figure 11).

\section{Conclusion}

The physical and geotechnical identifications, microstructure analysis and œdometer tests with unloading-reloading loops have been performed on the samples of Ypresian clays cored at Kallo 
(N-Belgium) in order to assess the Ypresian clays as a potential host formation for geological disposal of radioactive wastes. Ypresian clays have been identified as fine-grained soil, highly plastic, particularly porous with respect to their depths, and slightly carbonated except core YK43.

Significant variability in terms of physical and geotechnical properties and microstructure have been identified: i) the middle of the Roubaix Member (cores YK43 and YK64) presents lower plasticity indices, void ratio $e_{0}$, water content $w_{0}$ and higher density $\rho_{0}$ than the lower part of the Roubaix Member (core YK73) and the upper part of the Orchies Member (core YK95); ii) the microstructure of core YK43 (middle of the Roubaix Member) is characterized by the aggregate type with dominance of the silty grains and a sole dominant meso-pore family at $D=0.8 \mu \mathrm{m}$. The microstructure of core YK73 (lower part of the Roubaix Member) shows presence of a clay matrix in which are dispersed silty grains, forming a bi-modal porosity with dominant micropore $(D=0.06 \mu \mathrm{m})$ and meso-pore $(D=0.25 \mu \mathrm{m})$ families.

The œdometer compression curves of Ypresian clays are characterised by typical unloading reloading hysteretic loops, commonly observed for fine-grained soils in the literature. This feature have been interpreted, according to Cui et al. (2013), by the competition between the mechanical and physico-chemical effects which are separated by a swelling stress. This approach allowed (i) properly determining the yield stress $\sigma_{y}^{\prime}$ of Ypresian clays at Kallo, which are in good agreement with their geological history; (ii) better identifying the swelling capacity as well as its dependence on their loading history. A semi-logarithmic linear relationship between the swelling stress and initial void ratio, determined by common swelling tests and œdometer compression tests were obtained. This confirmed the swelling stress concept proposed by Cui et 
al. (2013) and showed the consistency between the different tests performed in this study as well as the tests reported by Van Marcke \& Laenen (2005).

549 The mechanical and hydraulic parameters deduced from odometer tests showed significant 550 variation over depth: the compressibility and swelling capacity increases while the hydraulic 551 conductivity decreases over depth despite the increasing porosity. The normalised compression 552 curves in the $I_{v}-\log \sigma_{v}$ plane properly described the deposition process: the deeper the soil, the 553 lower its in situ void index $I_{v 0}$. In addition, the Ypresian clays are characterised by stable 554 microstructure. The high carbonate content and aggregate type microstructure of YK43 were also 555 well identified by the distinct position of its $I_{v}-\log \sigma_{v}$ curve from those of the three other samples 556 in the ICL-SCL framework.

\section{References}

559 Aertsens, M., Dierckx, A., Put, M., Moors, H., Janssen, K., Van Ravestyn, L., De Cannière, P., 2005. Determination of the hydraulic conductivity, $\eta R$ and the apparent diffusion coefficient on Ieper Clay and Boom Clay cores from the Doel-1 and Doel-2b drillings. Report No. SCK-CEN-R-3589 02/MAe/P-9, SCK-CEN.

AFNOR., 1997. Essai de compressibilité sur matériaux fins quasi saturés avec chargement par paliers. XP P 94-090-1 (Vol. 1).

AFNOR., 1998. Mesure de la capacité d'adsorption de bleu de méthylène d'un sol ou d'un matériau rocheux. Détermination de la valeur de bleu de méthylène d'un sol ou d'un matériau rocheux par l'essai à la tache. NF P 94-068.

Agus, S., 2005. An experimental study on hydro-mechanical characteristics of compacted 
bentonite-sand mixtures. Bauhaus-University Weimar.

Armand, G., Noiret, A., Zghondi, J., Seyedi, D.M., 2013. Short- and long-term behaviors of drifts in the Callovo-Oxfordian claystone at the Meuse/Haute-Marne Underground Research Laboratory. Journal of Rock Mechanics and Geotechnical Engineering, 5, 221230.

ASTM., 2006. Standard Practice for Classification of Soils for Engineering Purposes (Unified Soil Classification System). ASTM D 2487 - 06.

Baldi, G., Hueckel, A., Peano, A., Pellegrini, R., 1991. Developments in modelling of thermohydro-geomechanical behaviour of Boom clay and clay-based buffer materials (No. EUR 13964 EN). Commission of the European Communities.

Baudet, B., Stallebrass, S., 2004. A constitutive model for structured clays. Géotechnique, 54(4), 269-278.

Burland, J.B., 1990. On the compressibiity and shear strength of natural clays. Géotechnique, 40(3), 329-378.

Cammaer, C., Cockaerts, G., Schiltz, M., 2009. Drilling and géological report ON-KALLO-1, ON-KALLO-2, ON-KALLO-3 (No. Samsuffit R2009-01). ONDRAF/NIRAS.

Carrier, W. D. (1985). Consolidation Parameters Derived From Index Tests. Geotechnique, $35(2), 211-213$

Chandler, R.J., 2000. Clay sediments in depositional basins: the geotechnical cycle (The 3rd Glossop Lecture). Quarterly Journal of Engineering Geology and Hydrogeology, 33(1), $5-39$. 
Coll, C., 2005. Endommagement des roches argileuses et perméabilité induite au voisinage d'ouvrage souterrains. Université Joseph Fourier-Grenoble 1, Grenoble.

Cotecchia, F., Chandler, R.J., 2000. A general framework for the mechanical behaviour of clays. Géotechnique, 50(4), 431-447.

Cui, Y.J., Nguyen, X.P., Tang, A.M., Li, X.L., 2013. An insight into the unloading/reloading loops on the compression curve of saturated clays. Applied Clay Science, 83-84, 343-348.

Dehandschutter, B., Vandycke, S., Sintubin, M., Vandenberghe, N., Gaviglio, P., Sizun, J.P., Wouters, L., 2004. Microfabric of fractured Boom Clay at depth: a case study of brittleductile transitional clay behaviour. Applied Clay Science, 26, 389-401.

Delage, P., Le, T.T., Tang, A.M., Cui, Y.J., Li, X.L., 2007. Suction effects in deep Boom Clay block samples. Géotechnique, 57, 239-244.

Deng, Y.F., Cui, Y.J., Tang, A.M., Nguyen, X.P., Li, X.L., Van Geet, M., 2011a. Investigating the pore-water chemistry effects on the volume change behaviour of Boom clay. Physics and Chemistry of the Earth, 36, 1905- 1912.

Deng, Y.F., Tang, A.M., Cui, Y.J., Nguyen, X.P., Li, X.L., Wouters, L., 2011b. Laboratory hydro-mechanical characterisation of Boom Clay at Essen and Mol. Physics and Chemistry of the Earth, 36, 1878- 1890.

Deng, Y.F., Tang, A.M., Cui, Y.J., Li, X.L., 2011c. Study on the hydraulic conductivity of Boom clay. Canadian Geotechnical Journal, 48, 1491-1470.

Deng, Y.F., Cui, Y.J., Tang, A.M., Li, X.L., Sillen, X., 2012. An experimental study on the secondary deformation of Boom Clay. Applied Clay Science, 59-60, 19-25. 
Dixon, D.A., Gray, M.N., Graham, J., 1996. Swelling and hydraulic properties of bentonites from Japan, Canada and USA (pp. 5-8). Presented at the second International Congress on Environmental Geotechnics, Osaka, Japan.

Gasparre, A., 2005. Advanced laboratory characterisation of London clay. Imperial College London.

Hong Z.S., Yin J., Cui Y.J., 2010. Compression Behaviour of Reconstituted Soils at High Initial Water Contents. Géotechnique, 60(9), 691-700.

Hong Z.S., Zeng L.L., Cui Y.J., Cai Y.Q., Cheng L., 2012. Compression Behaviour of Natural and Reconstituted Clays. Géotechnique, 62(4), 291-301.

Johnson, A.I., Moston, R.P., 1970. Relationship of consolidation characteristics and Atterberg limits for subsiding sediments in central California, USA. Presented at the International Symposium on Land Subsidence.

Le, T.T., Cui, Y.J., Munoz, J.J., Delage, P., Tang, A.M., Li, X.L., 2011. Studying the stresssuction coupling in soils using an oedometer equipped with a high capacity tensiometer. Front. Archit. Civ. Eng. China, 5(2), 160-170.

Lee, J.O., Cho, W.J., Chun, K.S., 1999. Swelling Pressures of a Potential Buffer Material for High-Level Waste Repository. Journal of the Korean Nuclear Society, 31, 139- 150.

Leroueil, S., Tavenas, F., Locat, J., 1984. Correlations between index tests and the properties of remoulded clays. Géotechnique, 35(2), 223-229.

Leroueil, S., Tavenas, F., Locat, J., 1985. Discussion: Correlations between index tests and the properties of remoulded clays. W. D. Carrier and J. F. Beckman. Géotechnique, 35(2), 223-226. 
Lima, A., 2011. Themo-Hydro-Mechanical behaviour of two deep Belgian clay formations: Boom and Ypresian clays. Universitat Politècnica de Catalunya, Spain.

Mitchell, J. K., Soga, K., 2005. Fundamentals of soil behavior. John Wiley \& Sons, Inc.

Nguyen, X.P., 2013. Étude du comportement chimico-hydro-mécanique des argiles raides dans le contexte du stockage géologique de déchets radioactifs. Ecole des Ponts ParisTech.

ONDRAF, 2001. Safety Assessment and Feasibility Interim Report 2 (No. SAFIR2).NIROND 2001-06.

Romero, M.E., 1999. Characterisation and thermo-hydro-mechanical behaviour of unsaturated Boom clay: an experimental study. Universitat Politècnica de Catalunya.

Skempton, A.W., 1944. Notes on the Compressibility of Clays.". Q. J. Geol. Soc. London, 100(14), 119-135.

Skempton, A.W., 1970. The consolidation of clays by gravitational compaction. Q. J. Geol. Sot., $125,373-411$.

Sridharan, A., Rao, A.S., Sivapullaiah, P.V., 1986. Swelling pressure of clay. Geotechnical Testing Journal, 9(1), 24-31.

Sultan, N., Cui, Y.J., Delage, P., 2010. Yielding and plastic behaviour of Boom Clay. Géotechnique, 60(9), 657-666.

Terzaghi, K., Peck, R.B., 1967. Soil Mechanics in Engineering Practice. John Wiley London.

Tran, N.L., 1980. L'essai au bleu de méthylène Un progrès dans la mesure et le contrôle de la propreté des granulats. Bulletin de liaison des laboratoires des ponts et chaussées, 107, 130-135. 
654 UCLouvain, 1998. Rapport d'essai forage Doel-1A. Laboratoire du Génie Civil, Université 655 Catholique de Louvain.

656 Van Marcke, P., 2009. Existing information on the Ypresian clays. In Meeting on the THMC characterisation of Ypresian clays.

658 Van Marcke, P., Laenen, B., 2005. The Ypresian clay as possible host rock for radioactive waste disposal: An evaluation. ONDRAF.

660 Vandenberghe, N., 2011. Qualitative \& quantitative mineralogical analyses of Ypresian clay. $661 \quad$ KULeuven.

662 Wang, Q., Tang, A.M., Cui, Y.J., Delage, P., Gatmiri, B., 2012. Experimental study on the 663 swelling behaviour of bentonite/claystone mixture. Engineering Geology, 124(1), 59-66.

664 Wroth, C.P., Wood, D.M., 1978. The correlation of Index Properties with Some Basic 665 Engineering Properties of Soils. Canadian Geotechnical Jounal, 15, 137-145.

666

667 
668

669

670

671

672

673

674

675

676

677

678

679

680

681

682

683

684

685

686

687

688

689

690

691

692

693

694

695

696

697

698

\section{List of tables}

Table 1: Mineralogical composition of Ypresian clays in bulk mass (after Vandenberghe, 2011)

Table 2: Mineralogical composition of Ypresian clays in clay-size fraction (after Vandenberghe, 2011)

Table 3: Physical properties of Ypresian clays

Table 4: Test program

\section{List of figures}

Figure 1: Thickness and depth of the top of Kortrijk formation (After ONDRAF, 2001)

Figure 2: Stratigraphical profile and system track of Ypresian clays at Kallo and soil core positions, modified from Cammaer et al. (2009) and Van Marcke \& Laenen (2005)

Figure 3: Particle-size distribution curves (after Vandenberghe, 2011)

Figure 4: Classification of Ypresian clays at Doel and Kallo

Figure 5: SEM photos of Ypresian clays at Kallo

Figure 6: Pore-size distribution curves of Ypresian clays

Figure 7: Vertical stress and displacement variations in high-pressure œdometer test

Figure 8: Vertical stress and displacement variations in low-pressure œdometer test

Figure 9: Low- (a) and high- (b) pressure œdometer compression curves on YK43

Figure 10: Low- (a) and high- (b) pressure œdometer compression curves on YK64

Figure 11: Low- (a) and high- (b) pressure odometer compression curves on YK73

Figure 12: Low- (a) and high- (b) pressure œdometer compression curves on YK95

Figure 13: Parameter definitions

Figure 14: Swelling stress $\sigma_{s}$ versus (initial) void ratio $(e i) e$ for Ypresian clay

Figure 15: Variations of $C_{s e}, C_{c e}(\mathrm{a}), C_{s p}$ and $C_{c p}$ (b) versus preconsolidation stress $\sigma_{p}^{\prime}$

Figure 16: Compression index $C_{c}(\mathrm{a})$ and yield stress $\sigma_{y}^{\prime}(\mathrm{b})$ profiles

Figure 17: Secondary compression/swelling coefficient

Figure 18: Permeability of Ypresian clays

Figure 19: Hydraulic conductivity profile for Ypresian clays at Doel (after Aertsons et al., 2005)

Figure 20: Normalized compression curves

Figure 21: Pore-size distribution curves of intact and after HPO test YK73

Figure 22: SEM on intact (left) and after LPO test (right) YK43 
Table 1: Mineralogical composition of Ypresian clays in bulk mass (after Vandenberghe, 2011)

\begin{tabular}{|c|c|c|c|c|c|c|c|c|c|c|c|}
\hline \multirow{2}{*}{ Core } & \multirow{2}{*}{$\begin{array}{l}\text { Depth } \\
\text { (m) }\end{array}$} & \multicolumn{5}{|c|}{$\begin{array}{l}\text { composition of Ypresian clays } \\
\text { Non-clay minerals (wt \%) }\end{array}$} & \multicolumn{5}{|c|}{$\begin{array}{l}\text { Clay minerals (wt \%) } \\
\text { Clandentergne, } 0 \text { ) }\end{array}$} \\
\hline & & Qtz & Feld. & Car. & Others & $\Sigma_{\mathrm{NC}}$ & Kaol. & Chl. & Sm. Eq. & Ill. Eq. & $\Sigma_{\mathrm{C}}$ \\
\hline YK44 & 331.48 & 32 & 12 & 2 & 0.4 & 46 & 2 & 3 & 33.7 & 15.3 & 54 \\
\hline YK63 & 350.41 & 36 & 13 & 1.7 & 1.7 & 52 & 5 & 3 & 30.8 & 9.2 & 48 \\
\hline YK74 & 361.29 & 31 & 11 & 0.8 & 0.4 & 43 & 3 & 4 & 28.8 & 21.2 & 57 \\
\hline YK96 & 383.01 & 27 & 10 & 4 & 0.8 & 42 & 3 & 3 & 30.4 & 22.6 & 59 \\
\hline
\end{tabular}

701

Table 2: Mineralogical composition of Ypresian clays in clay-size fraction (after Vandenberghe, 2011)

\begin{tabular}{|c|c|c|c|c|c|c|c|c|c|c|c|c|c|}
\hline \multirow[b]{2}{*}{ Core } & \multicolumn{8}{|c|}{ Relative to clay-size fraction (wt \%) } & \multicolumn{5}{|c|}{ Relative to total mass (wt \%) } \\
\hline & $\begin{array}{r}\text { Ill } \\
\text { (wt } \%\end{array}$ & $\begin{array}{l}\mathrm{n} . \\
\mathrm{oSm} .)\end{array}$ & Ill. & Sm. & Kaol. & Chl. & $\Sigma \mathrm{Sm}$. & $\Sigma 2: 1$ & $\Sigma 2: 1$ & Ill.-Sm. & Ill. & Sm. & $\Sigma \mathrm{Sm}$. \\
\hline YK44 & 24 & 38 & 9 & 63 & 2 & 2 & 72 & 96 & 49 & 12 & 5 & 32 & 37 \\
\hline YK63 & 24 & 33 & 9 & 62 & 1 & 4 & 70 & 95 & 40 & 10 & 4 & 26 & 29 \\
\hline YK74 & 22 & 38 & 10 & 63 & 2 & 3 & 71 & 95 & 50 & 12 & 5 & 33 & 38 \\
\hline YK96 & 23 & 37 & 10 & 59 & 3 & 5 & 68 & 92 & 53 & 13 & 6 & 34 & 39 \\
\hline
\end{tabular}

703

704

705

706

707

708

709 710 711 712 713 714

715

\section{9} 715

Qtz: Quartz; Feld.: Feldspar; Car.: Carbonates; Others: Plagioclase, dolomite, Pyrite, Anatase, Opal CT and Zeolite; $\Sigma_{N C}$ : Total non-clay minerals; Kaol.: Kaolinite; Chl.: Chlorite; Sm. Eq. = equivalent of smectite in the bulk rock based on the CEC results assuming an average smectite with a charge of 100meq/100g; Ill. Eq. = equivalent of illite(/muscovite) in the bulk rock calculated as $\Sigma 2: 1$ - sm. Eq; $22: 1$ : di-octahedral clays (illite, smectite, illitesmectite, glauconite) and micas; $\Sigma C$ : Total clay minerals; $\Sigma S m .=S m .+$ Ill. $-S m . \times \%$ Sm., is the total smectite content 
716

Table 3: Physical properties of Ypresian clays

\begin{tabular}{lcccc} 
Core & YK43 & YK64 & YK73 & YK95 \\
\hline $\mathrm{G}_{\mathrm{s}}(-)$ & 2.776 & 2.785 & 2.802 & 2.802 \\
$\rho_{0}\left(\mathrm{Mg} / \mathrm{m}^{3}\right)$ & $1.97 \pm 0.03$ & $1.97 \pm 0.01$ & $1.9 \pm 0.01$ & $1.91 \pm 0.05$ \\
$\rho_{\mathrm{d} 0}\left(\mathrm{Mg} / \mathrm{m}^{3}\right)$ & 1.57 & 1.55 & 1.43 & 1.47 \\
$\mathrm{e}_{0}(-)$ & $0.77 \pm 0.03$ & $0.79 \pm 0.03$ & $0.95 \pm 0.06$ & $0.90 \pm 0.06$ \\
$\mathrm{n}_{0}(\%)$ & $44 \pm 1.1$ & $44 \pm 1.1$ & $49 \pm 1.6$ & $47 \pm 1.5$ \\
$\mathrm{LL}(-)$ & 75.07 & 113.84 & 136.61 & 132.22 \\
$\mathrm{PL}(-)$ & 33.50 & 33.75 & 36.08 & 43.75 \\
$\mathrm{PI}(-)$ & 41.57 & 80.09 & 100.53 & 88.47 \\
$\mathrm{w}_{0}(\%)$ & $25.78 \pm 0.73$ & $26.74 \pm 1.86$ & $32.01 \pm 1.56$ & $29.78 \pm 1.94$ \\
$\mathrm{~S}_{\mathrm{r} 0}(\%)$ & $93 \pm 3$ & $95 \pm 4$ & $96 \pm 4$ & $93 \pm 5$ \\
$\mathrm{~S}_{\mathrm{s}}\left(\mathrm{m}^{2} / \mathrm{g}\right)$ & 83 & 149 & 275 & 267 \\
$\mathrm{VBS}(\mathrm{g} / 100 \mathrm{~g})$ & 3.95 & 7.09 & 13.12 & 12.72 \\
$\% \mathrm{CaCO}(\mathrm{g} / 100 \mathrm{~g})$ & 10.2 & 1.4 & 0.9 & 3.8 \\
\hline
\end{tabular}

718

719

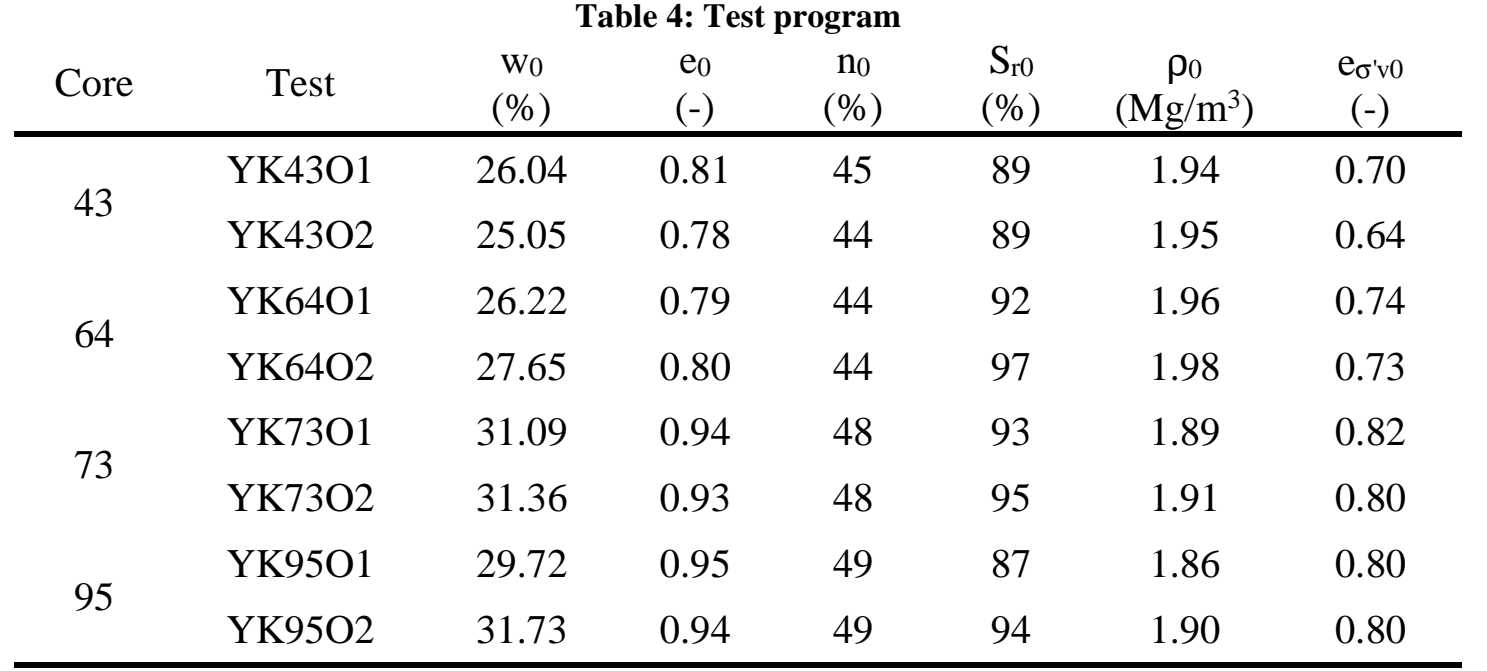


Depth TAW ( $m$ below sea level) of the top of the Kortrijk formation Thickness of the Kortrijk formation

$+150 \mathrm{~m}$

$100-150 \mathrm{~m}$

$50 \cdot 100 \mathrm{~m}$

$0.50 \mathrm{~m}$

Outcrop of the Kortrijk formation THE NETHERLANDS

North Sea

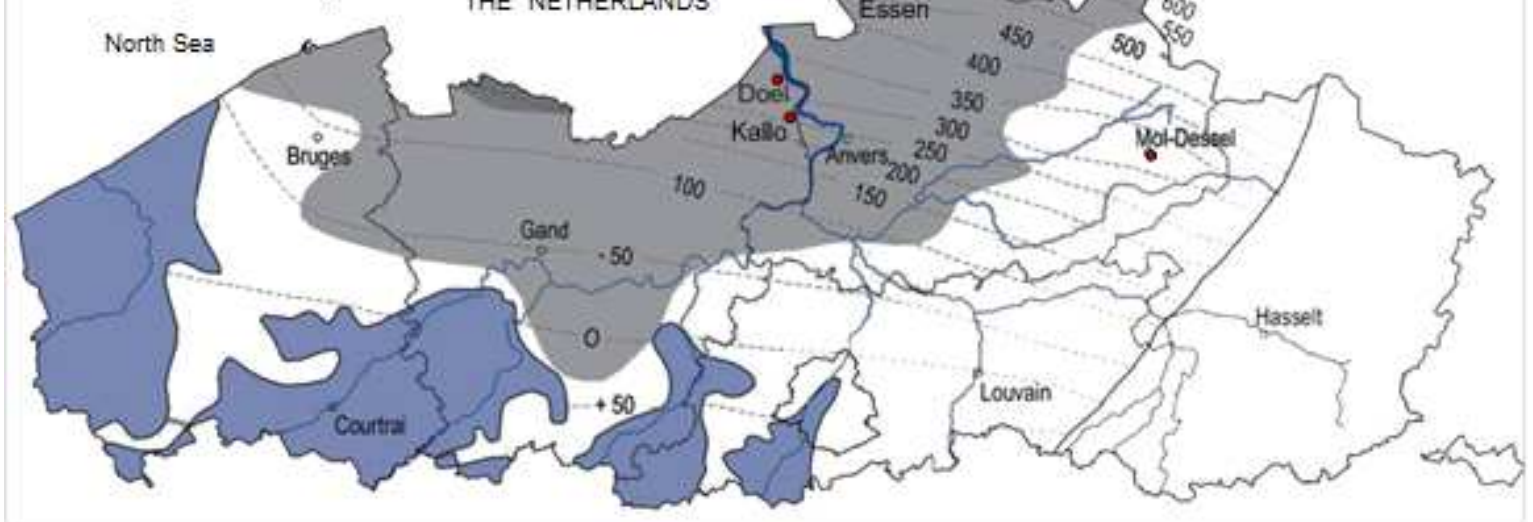

Figure 1: Thickness and depth of the top of Kortrijk formation (After ONDRAF, 2001) 


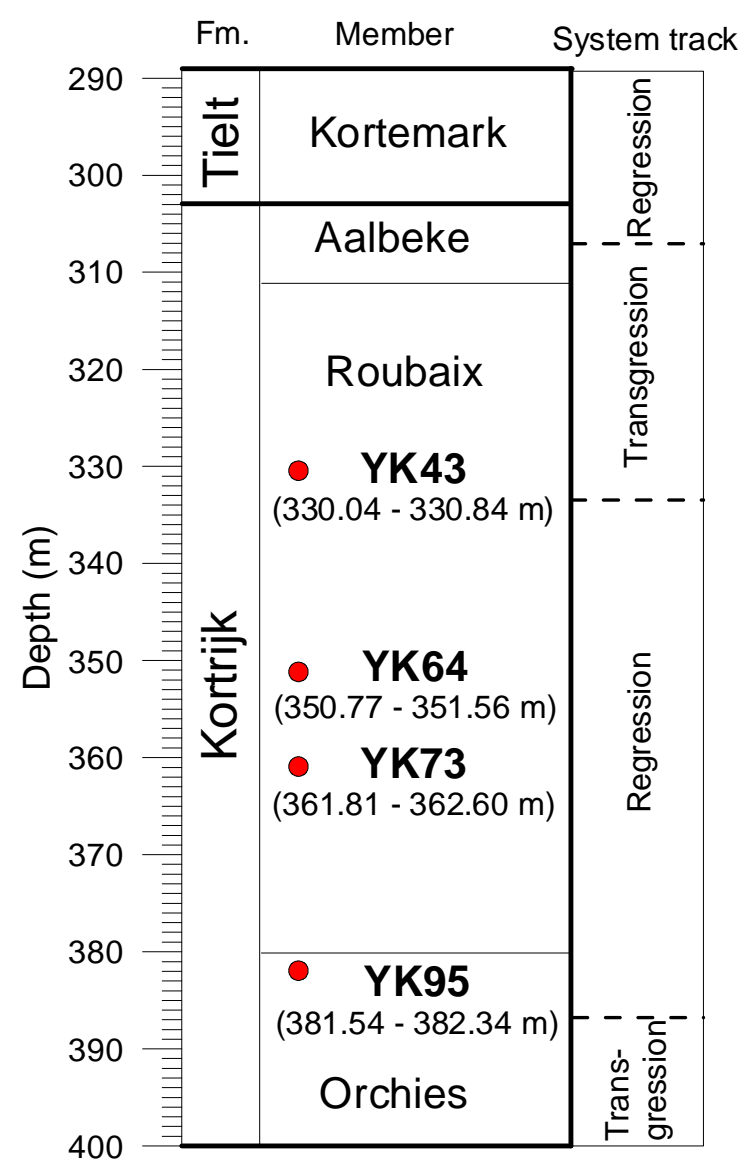

Figure 2: Stratigraphical profile and system track of Ypresian clays at Kallo and soil core positions, modified from Cammaer et al. (2009) and Van Marcke \& Laenen (2005) 


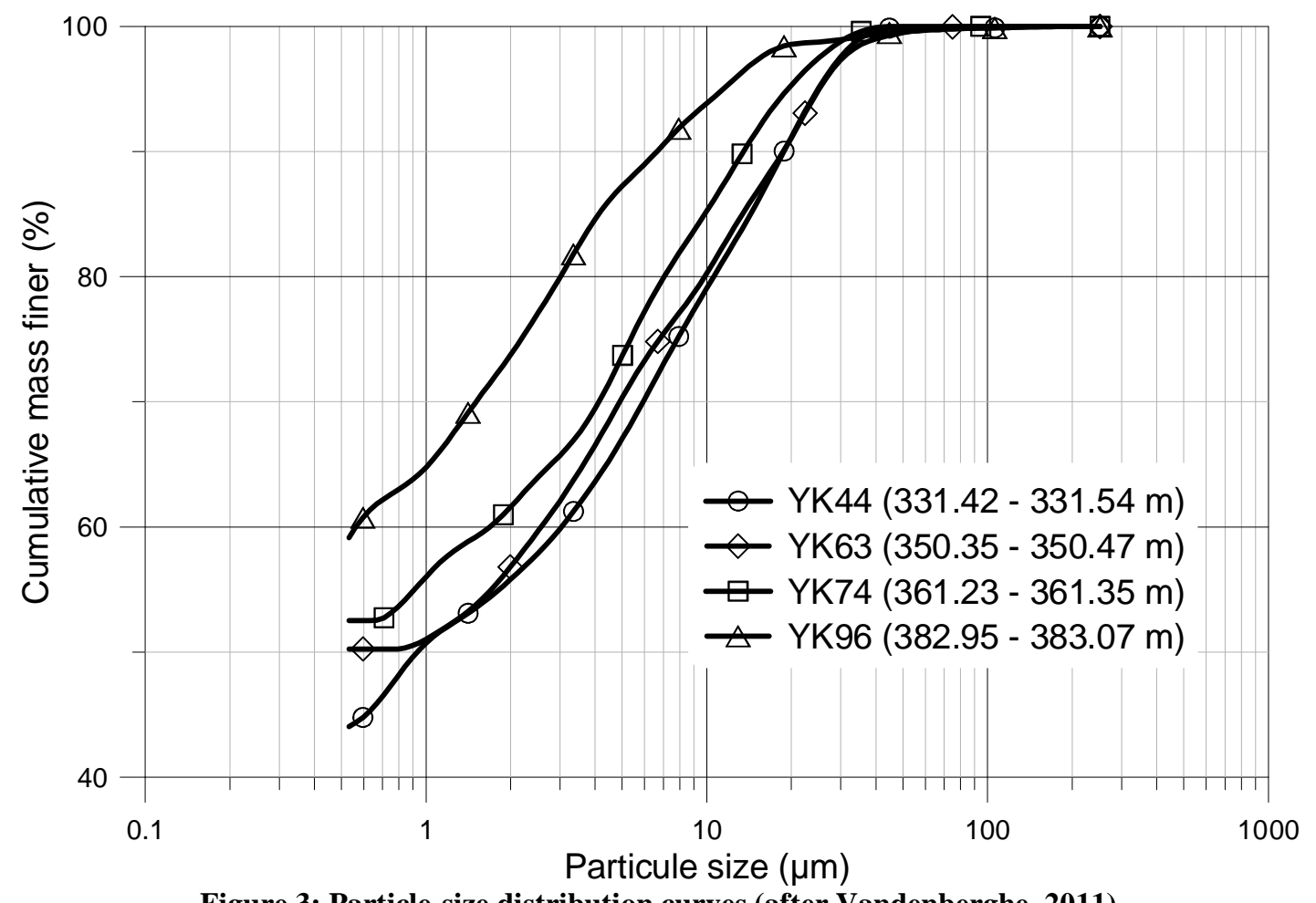

Figure 3: Particle-size distribution curves (after Vandenberghe, 2011)

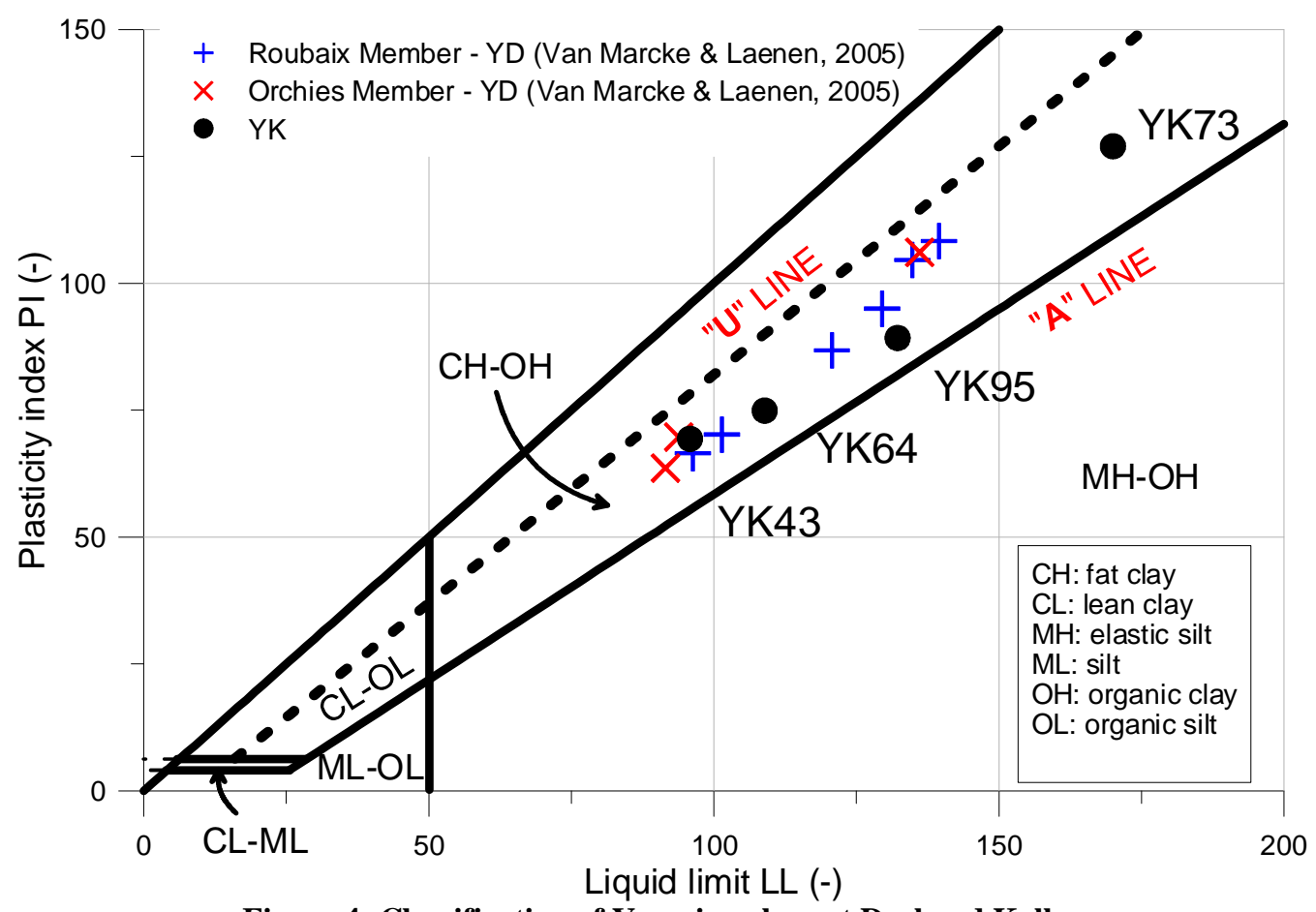

Figure 4: Classification of Ypresian clays at Doel and Kallo 
YK43, 625×500 $\mu \mathrm{m}$

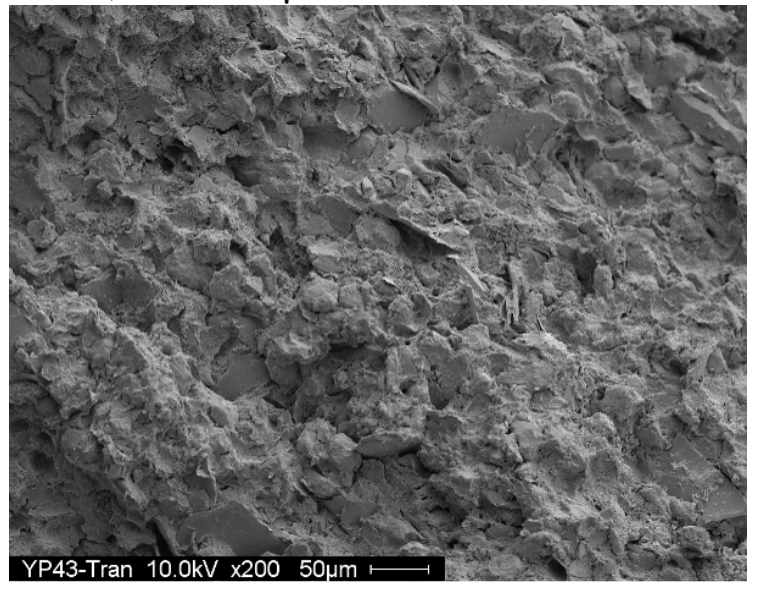

YK64, $625 \times 500 \mu \mathrm{m}$

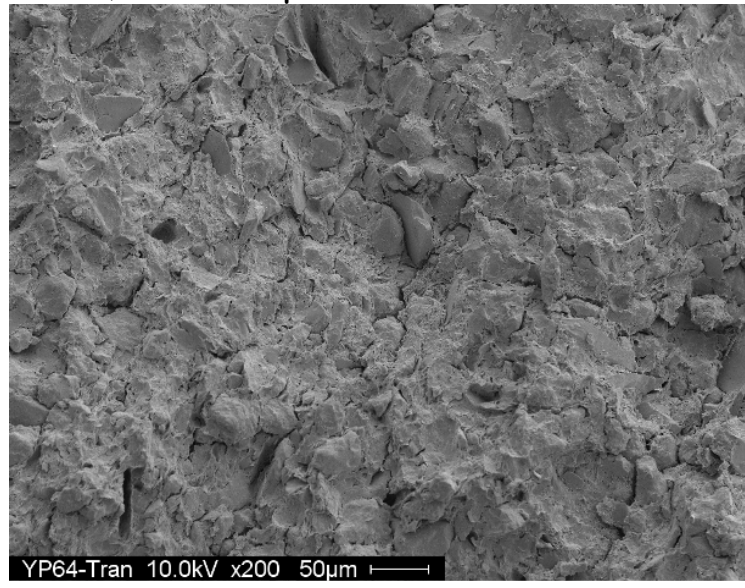

YK73, 125×100 $\mu \mathrm{m}$

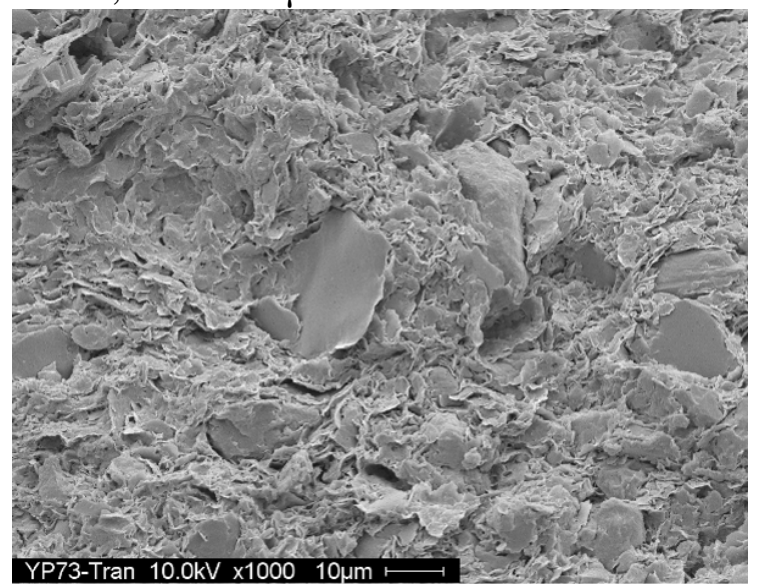

$\mathrm{YK} 43,125 \times 100 \mu \mathrm{m}$

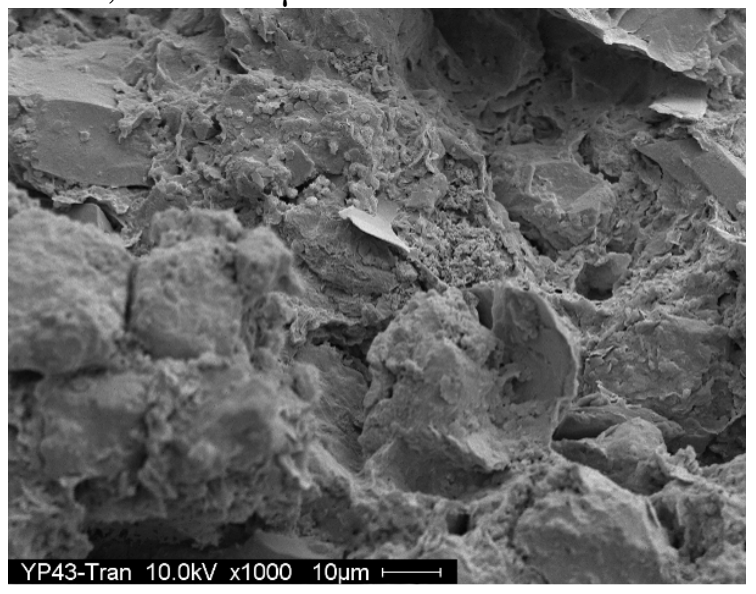

YK64, 125×100 $\mu \mathrm{m}$

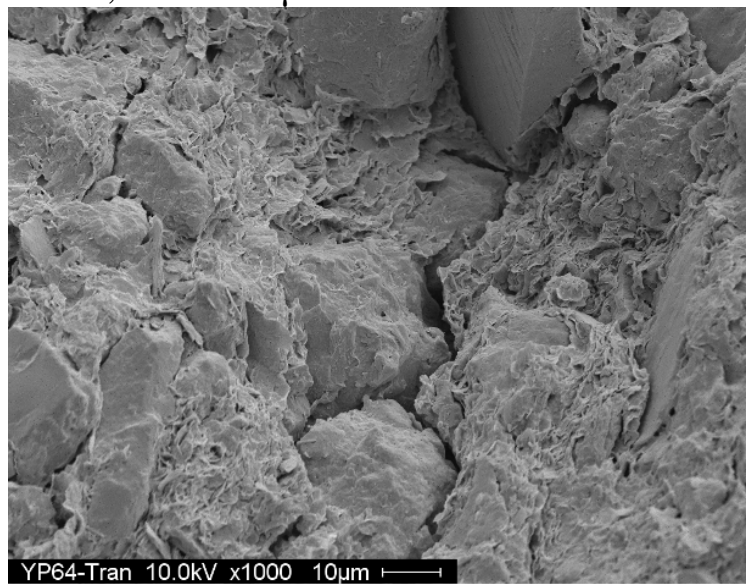

YK73, 25×20 $\mu \mathrm{m}$

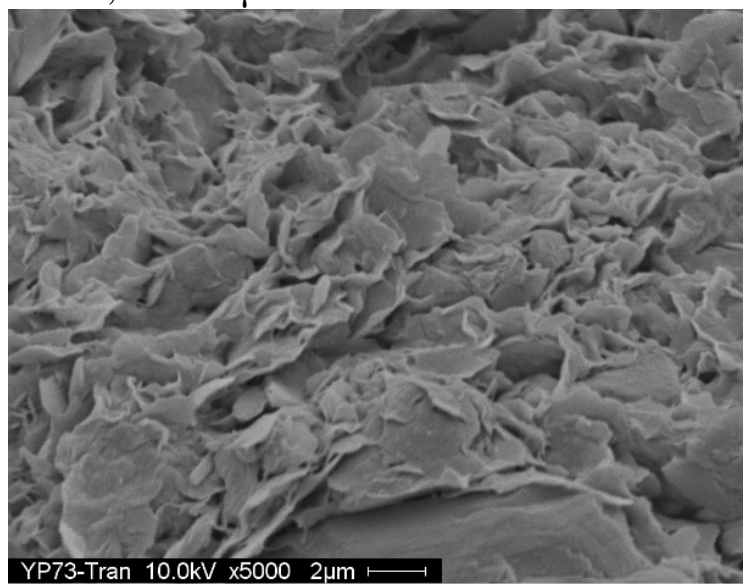


YK95, $125 \times 100 \mu \mathrm{m}$

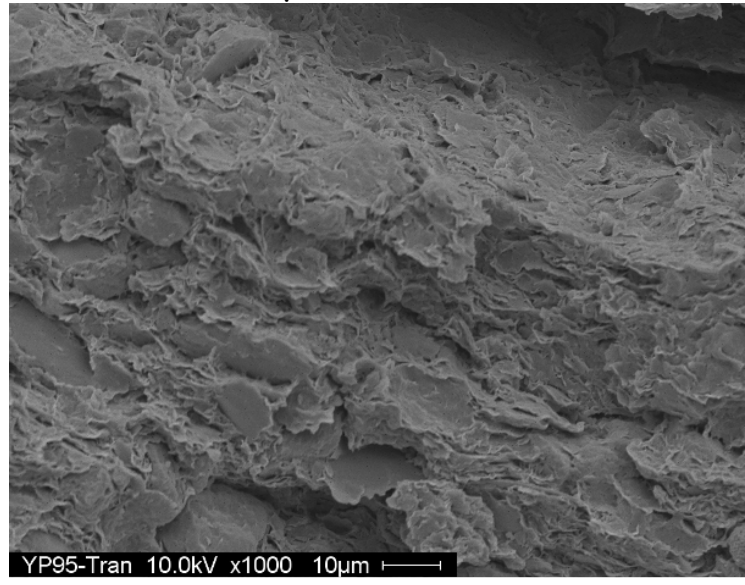

YK95, 25×20 $\mu \mathrm{m}$

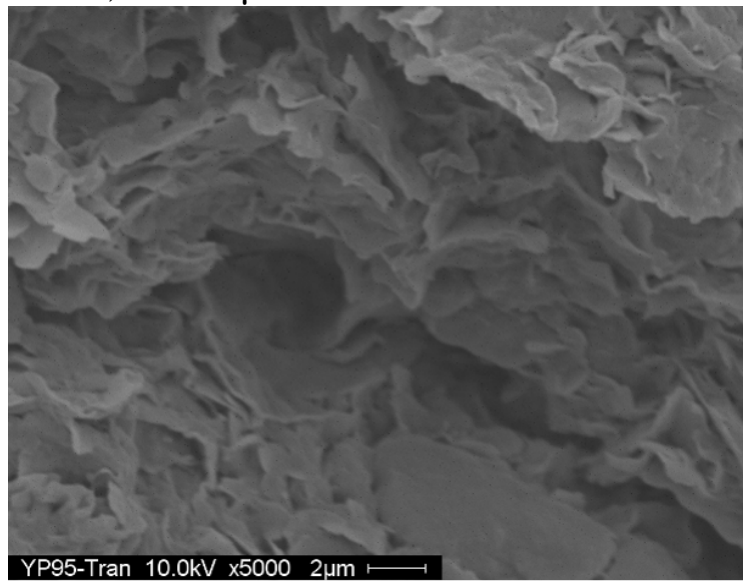

Figure 5: SEM photos of Ypresian clays at Kallo
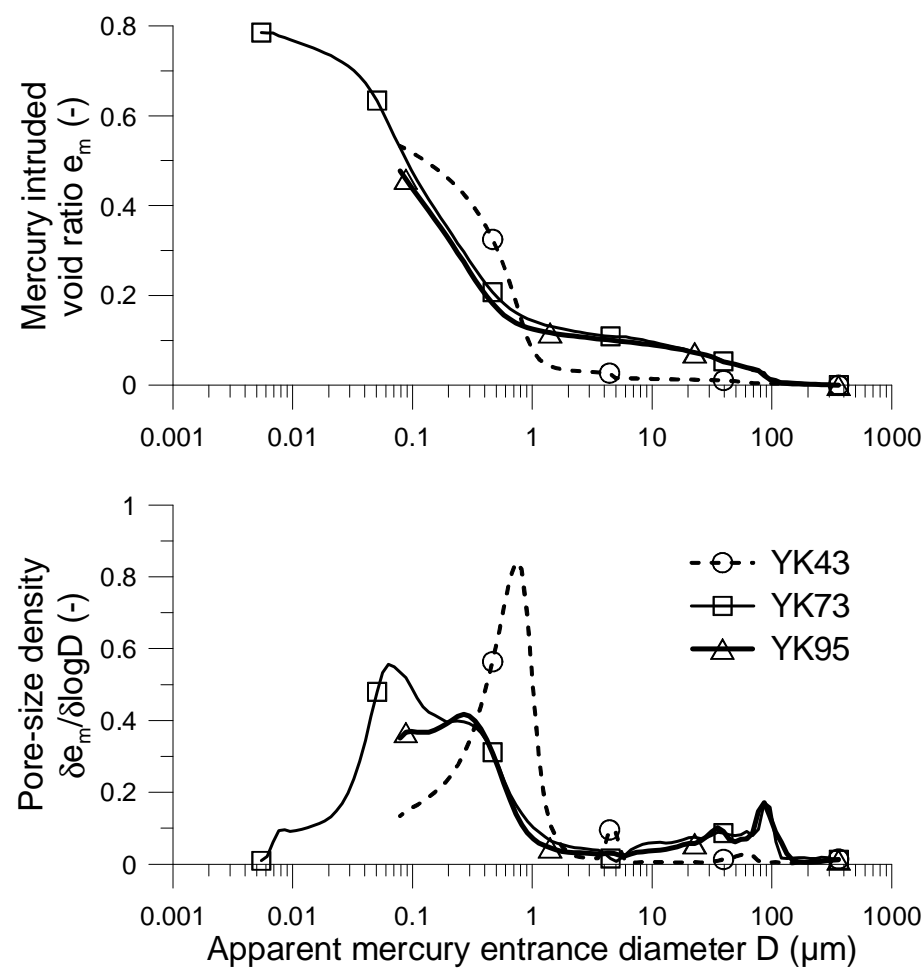

Figure 6: Pore-size distribution curves of Ypresian clays 


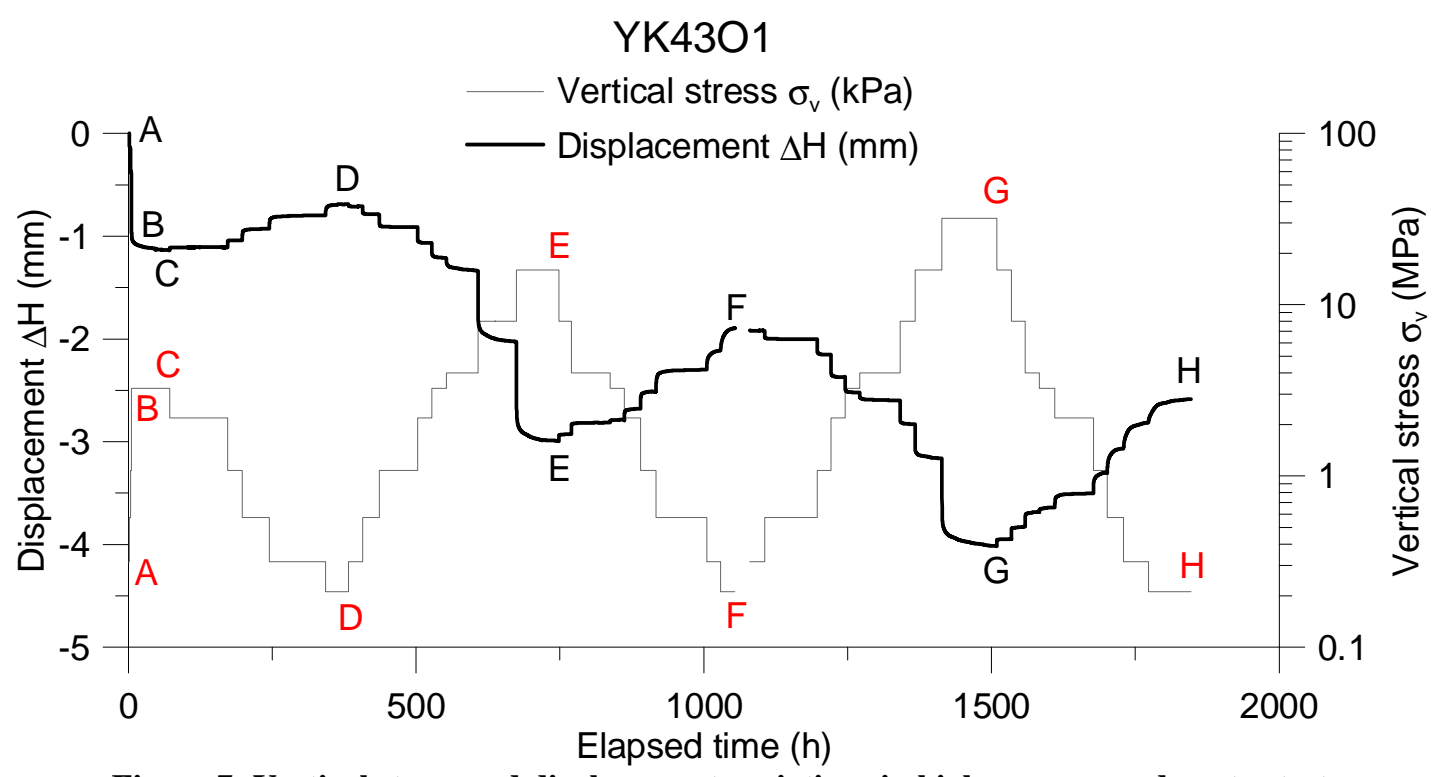

739

Figure 7: Vertical stress and displacement variations in high-pressure oedometer test

741

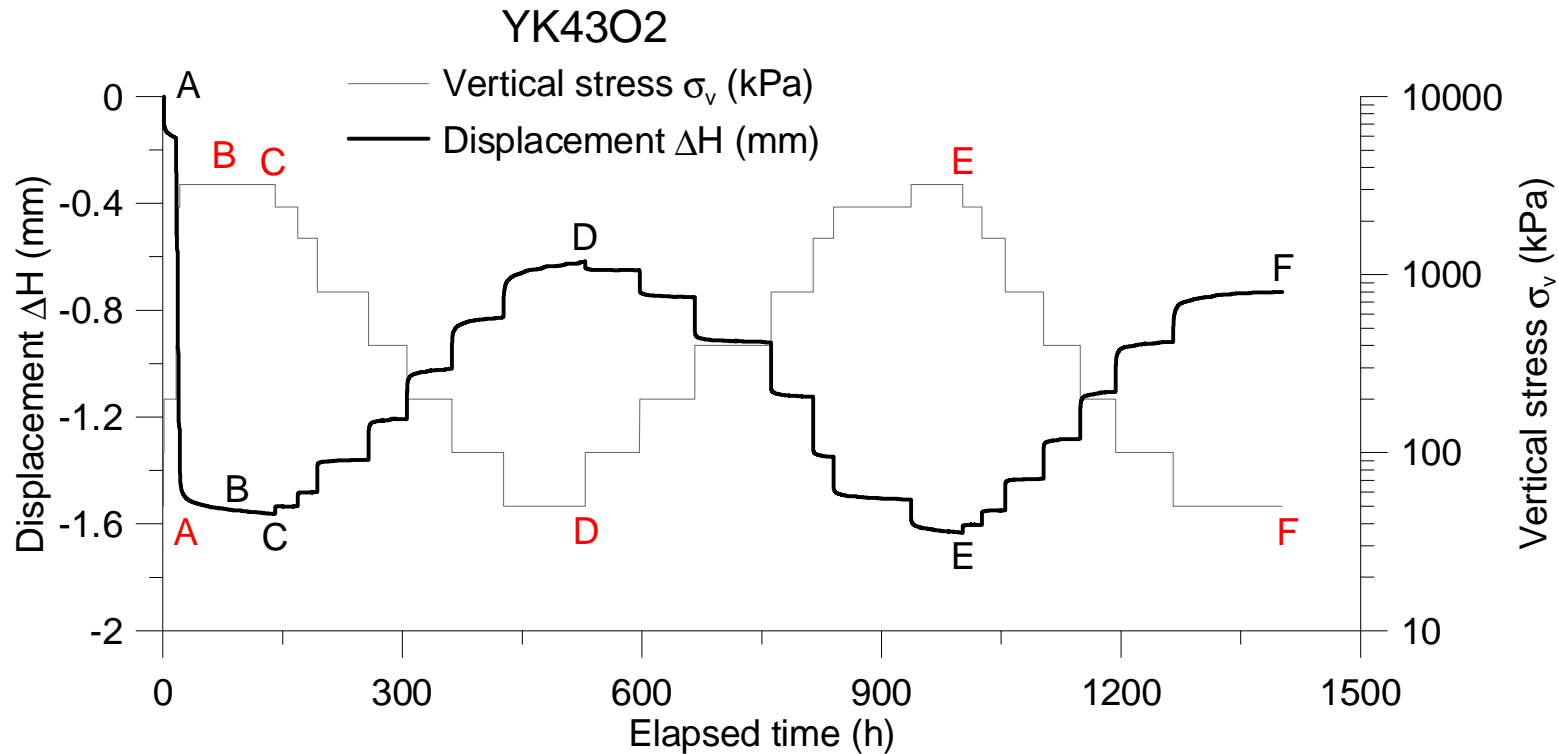

Figure 8: Vertical stress and displacement variations in low-pressure oedometer test 

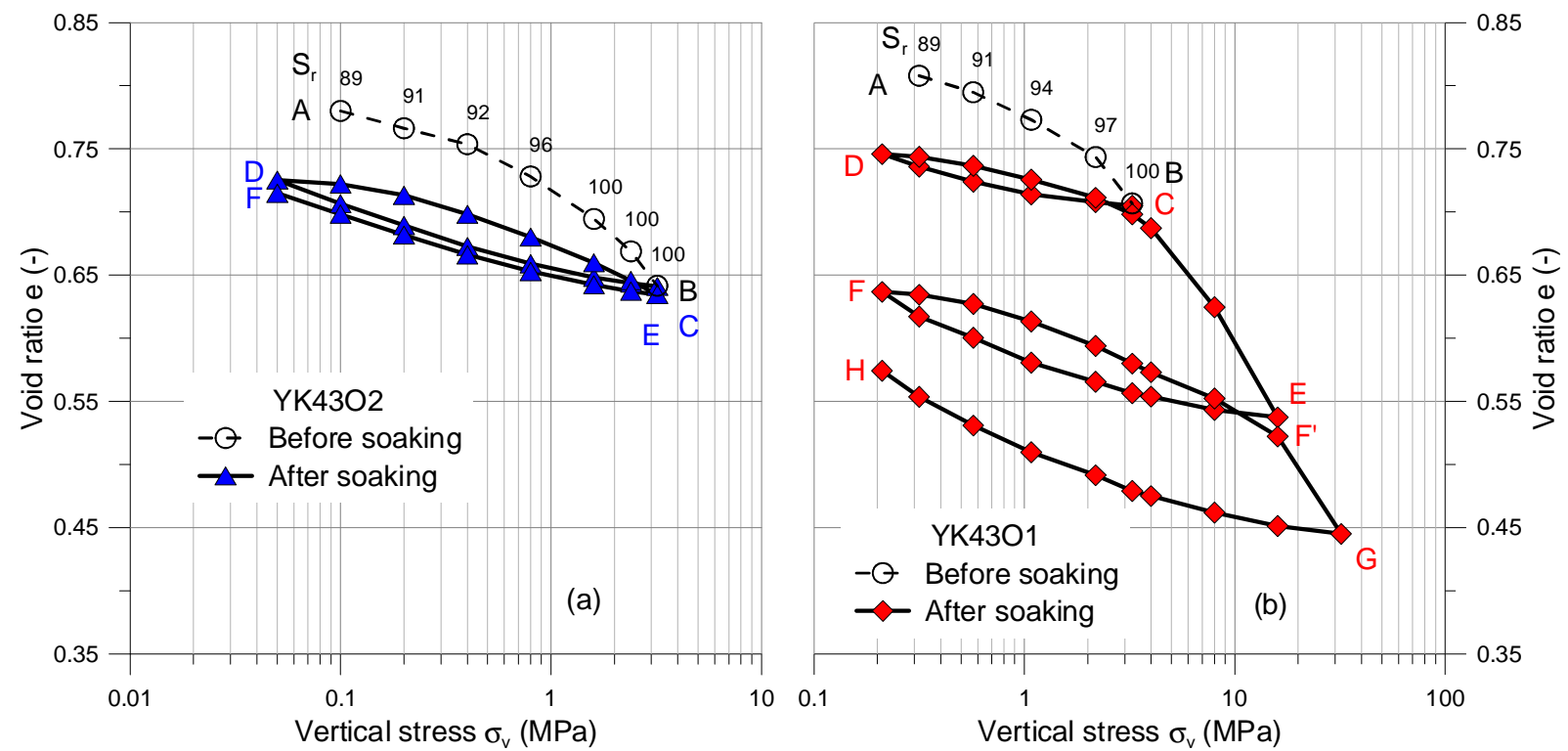

Figure 9: Low- (a) and high- (b) pressure odometer compression curves on YK43
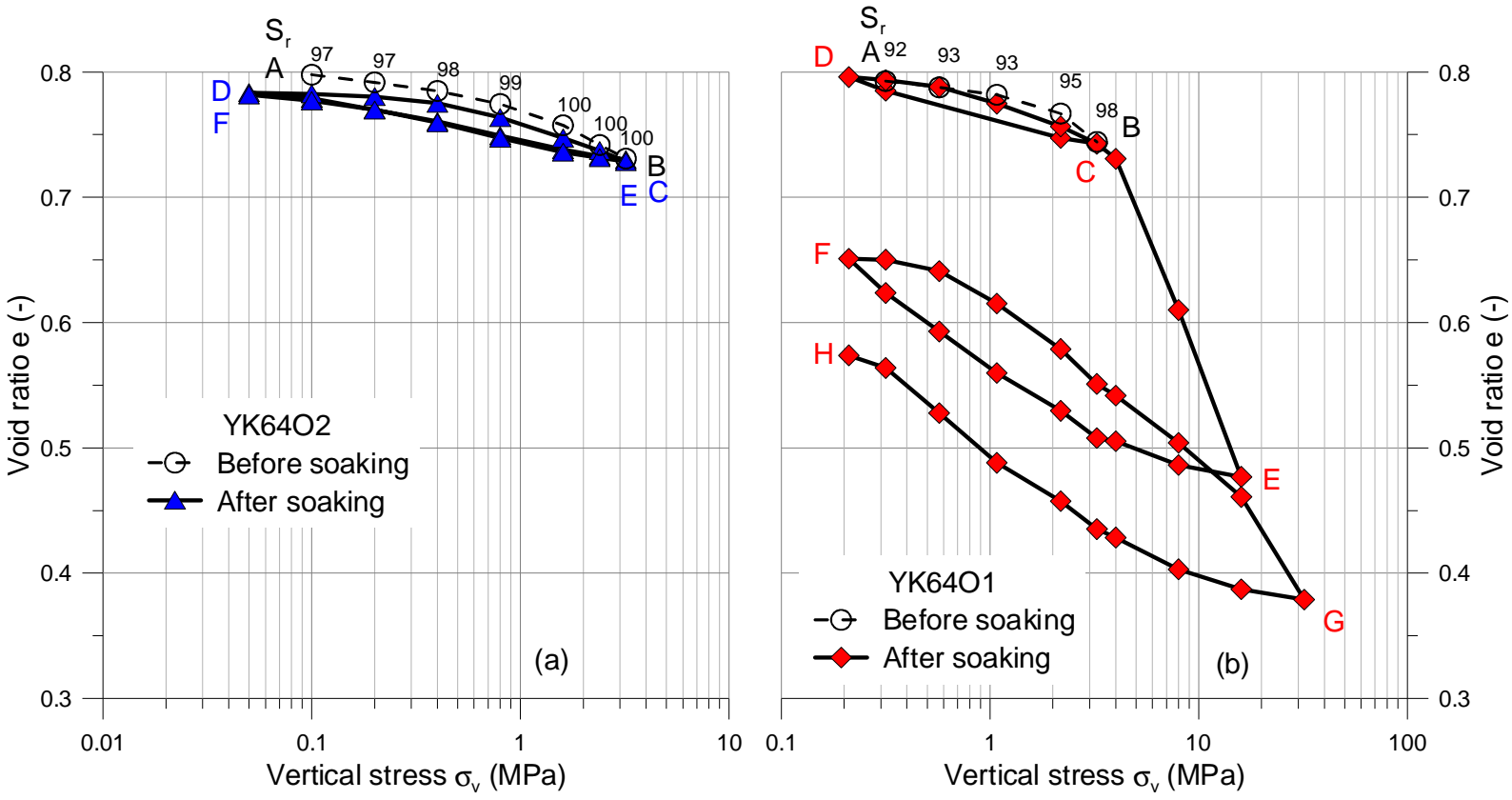

Figure 10: Low- (a) and high- (b) pressure odometer compression curves on YK64 

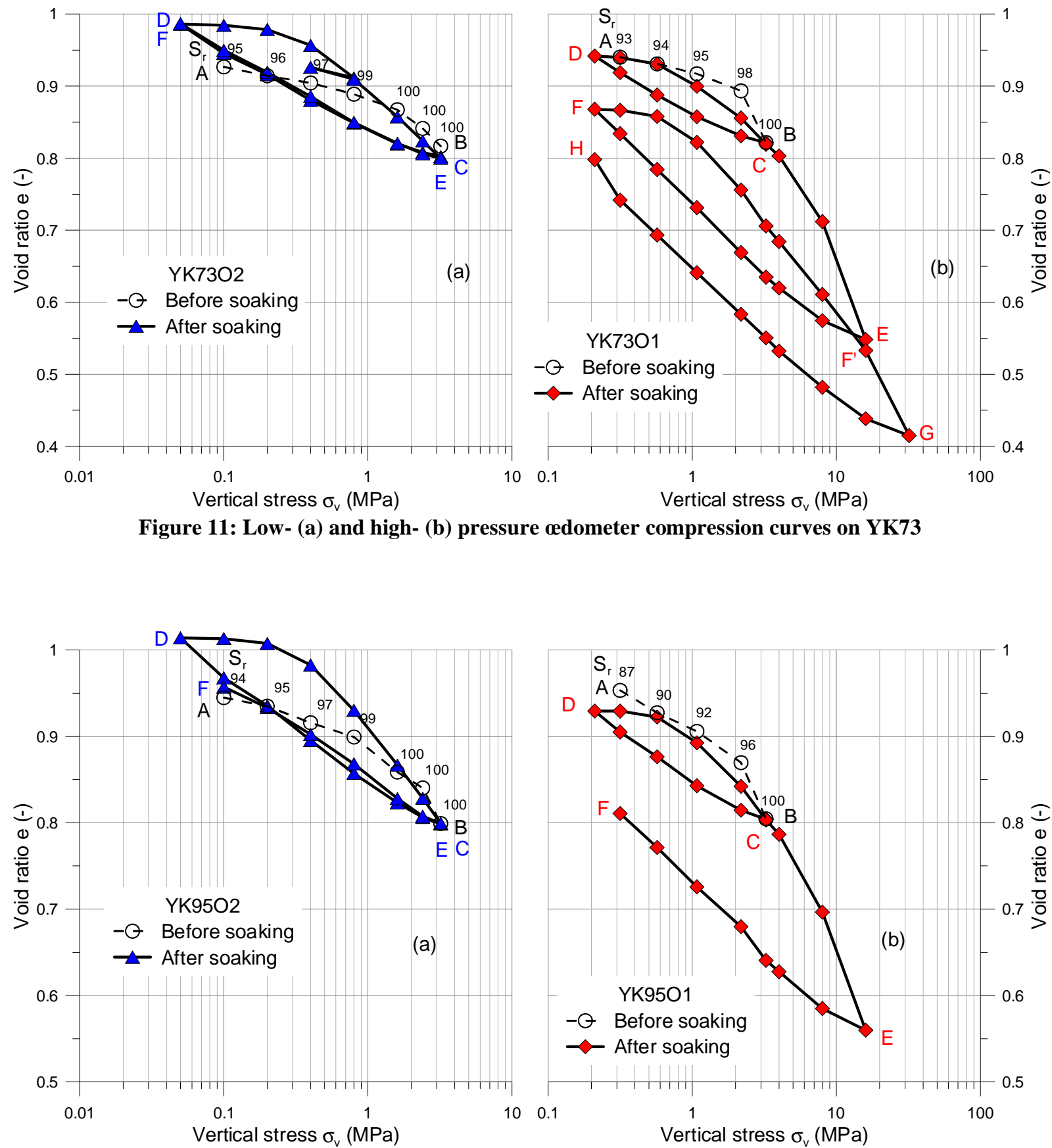

Figure 12: Low- (a) and high- (b) pressure odometer compression curves on YK95 


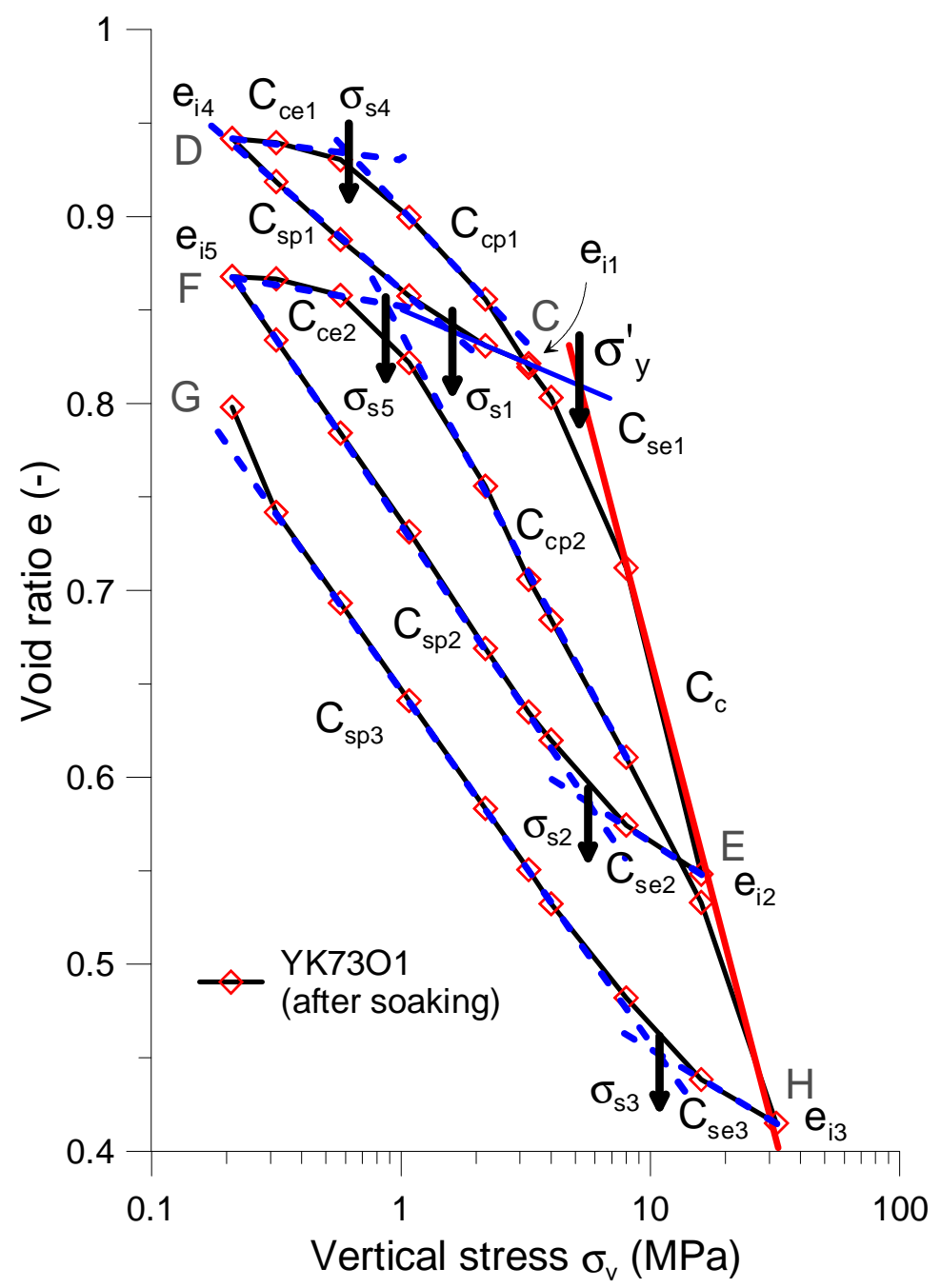

757
758

Figure 13: Parameter definitions 


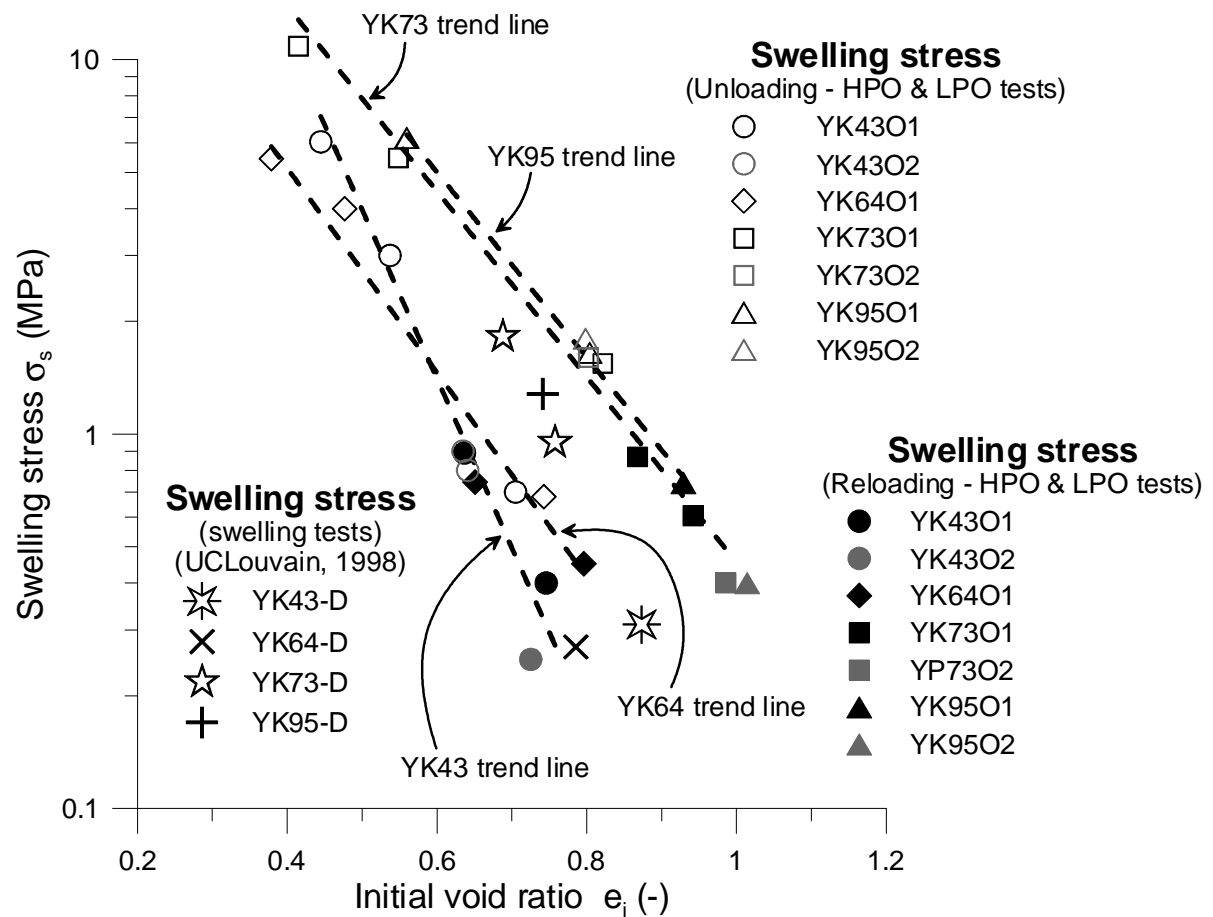

762

Figure 14: Swelling stress $\sigma_{s}$ versus (initial) void ratio $\left(e_{i}\right) e$ for Ypresian clay

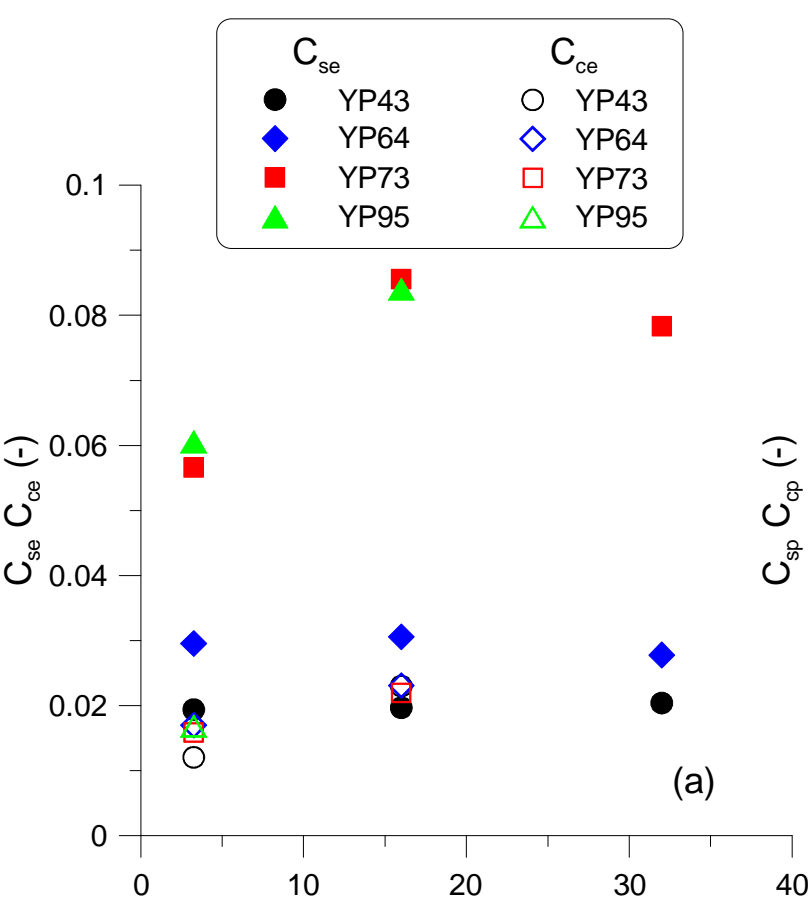

Preconsolidation stress $\sigma_{p}^{\prime}(\mathrm{MPa})$

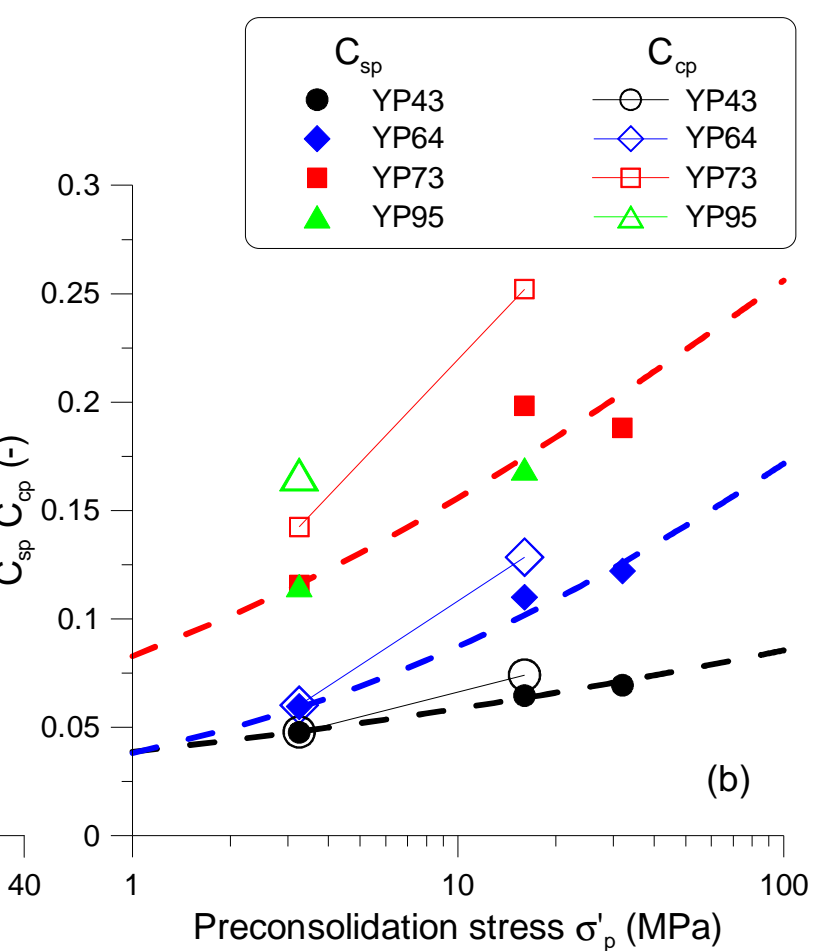

Preconsolidation stress $\sigma_{p}^{\prime}(\mathrm{MPa})$

Figure 15: Variations of $C_{s e}, C_{c e}(\mathbf{a}), C_{s p}$ and $C_{c p}(\mathrm{~b})$ versus preconsolidation stress $\sigma_{p}$ 

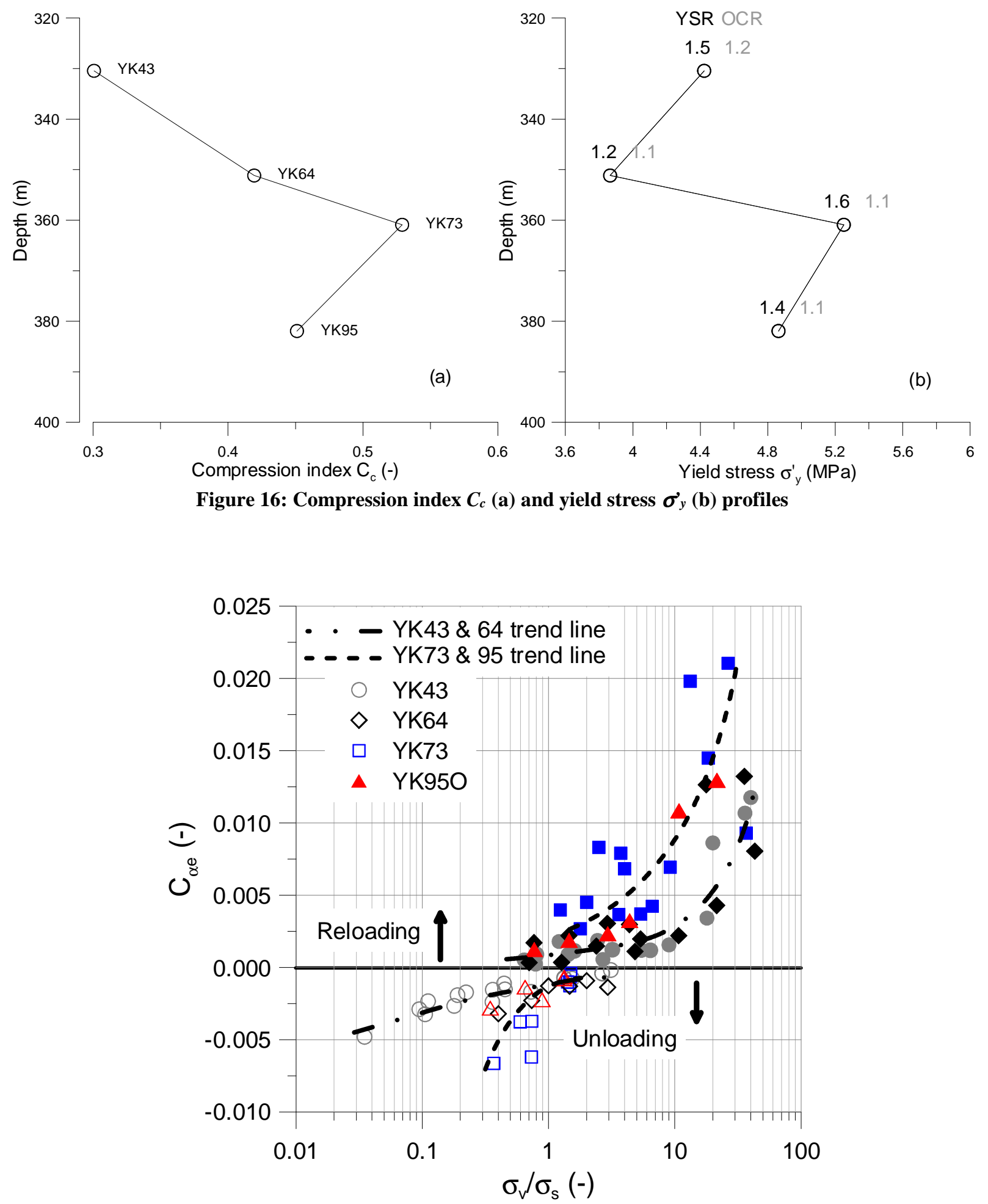

Figure 17: Secondary compression/swelling coefficient 


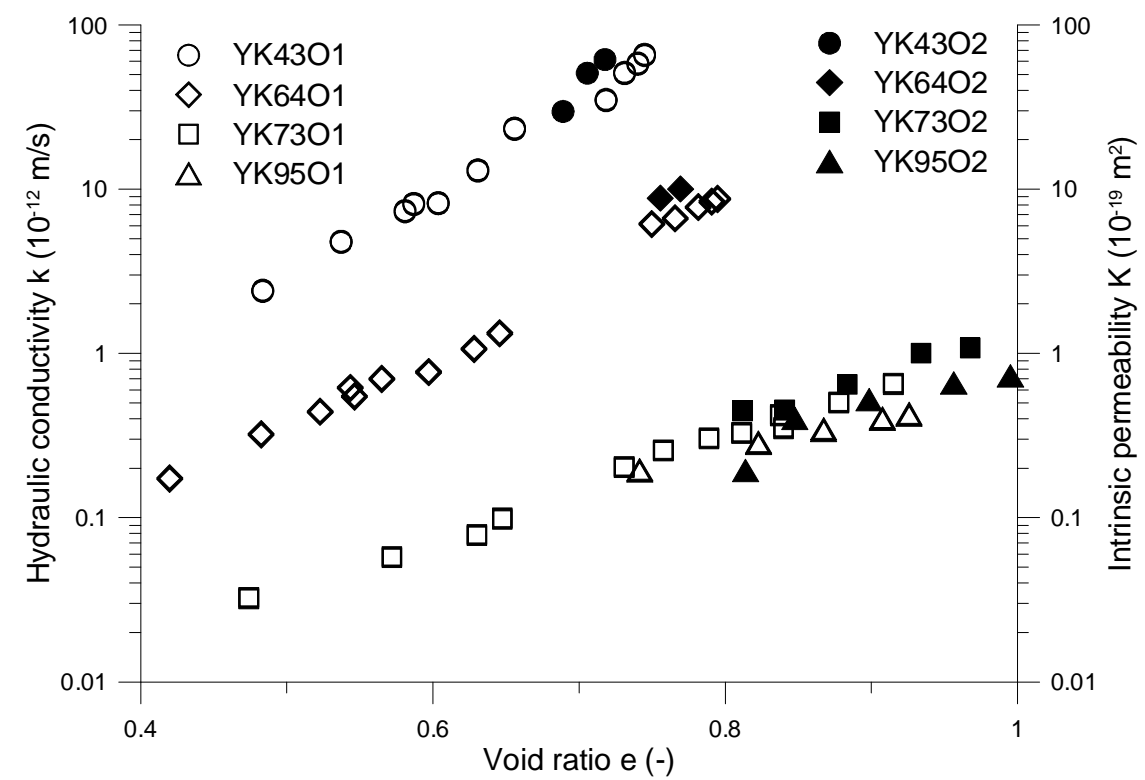

Figure 18: Permeability of Ypresian clays

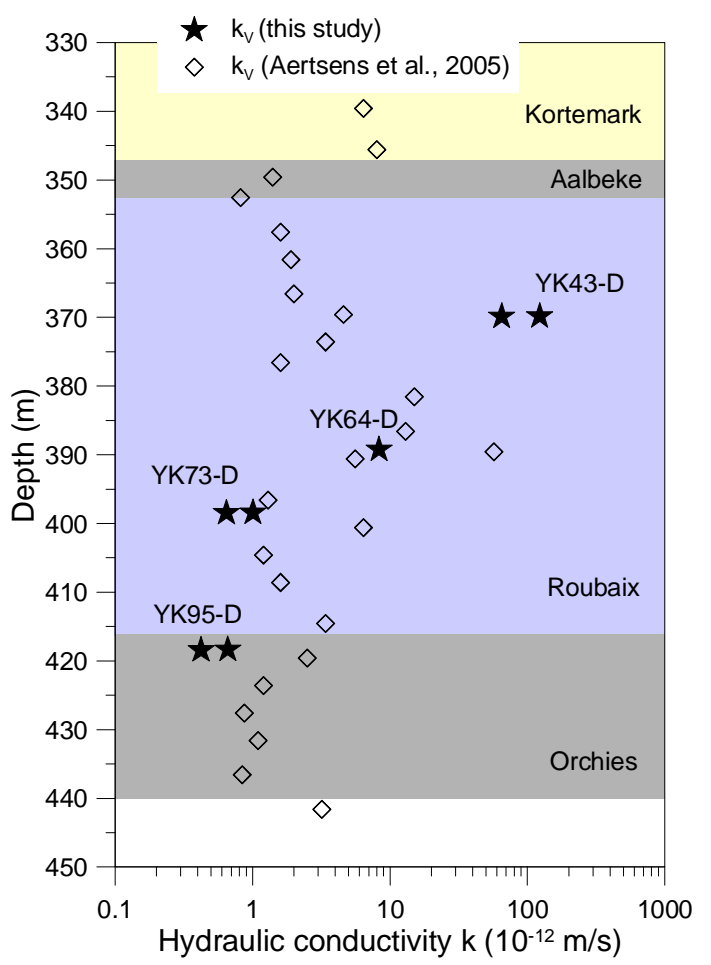




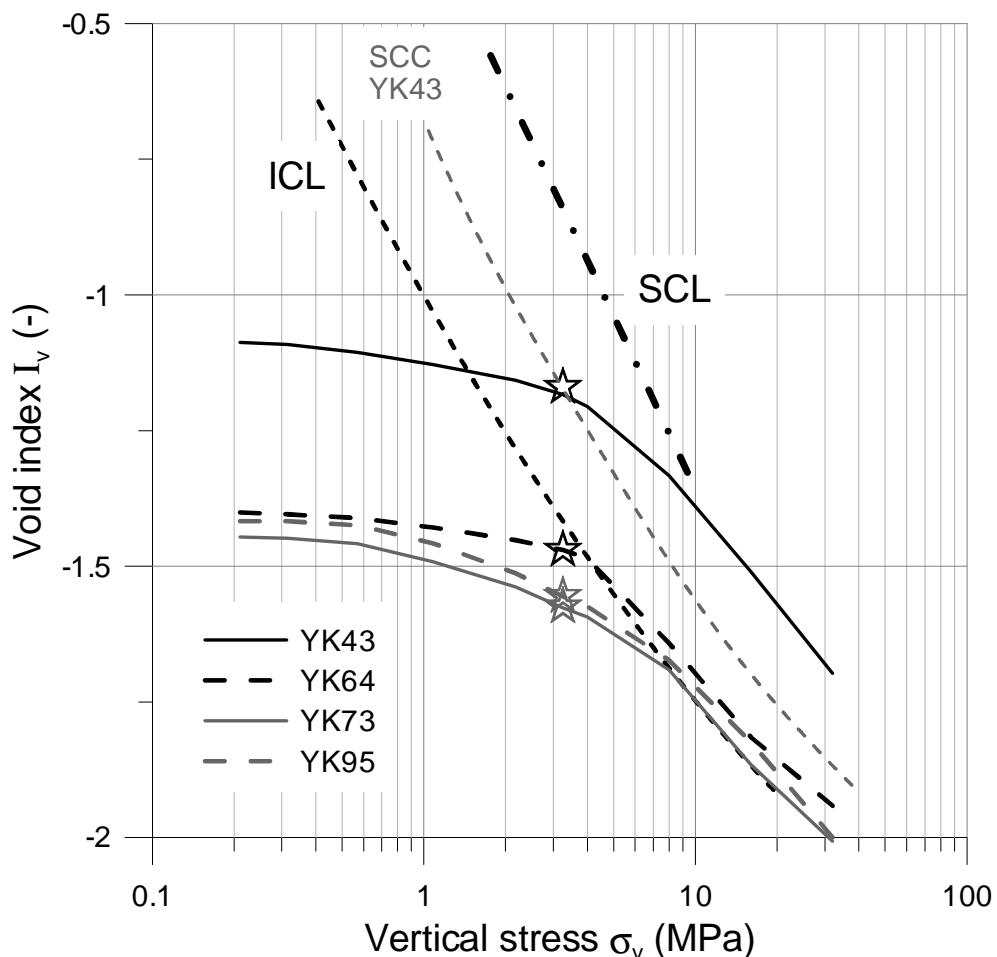

Figure 20: Normalized compression curves
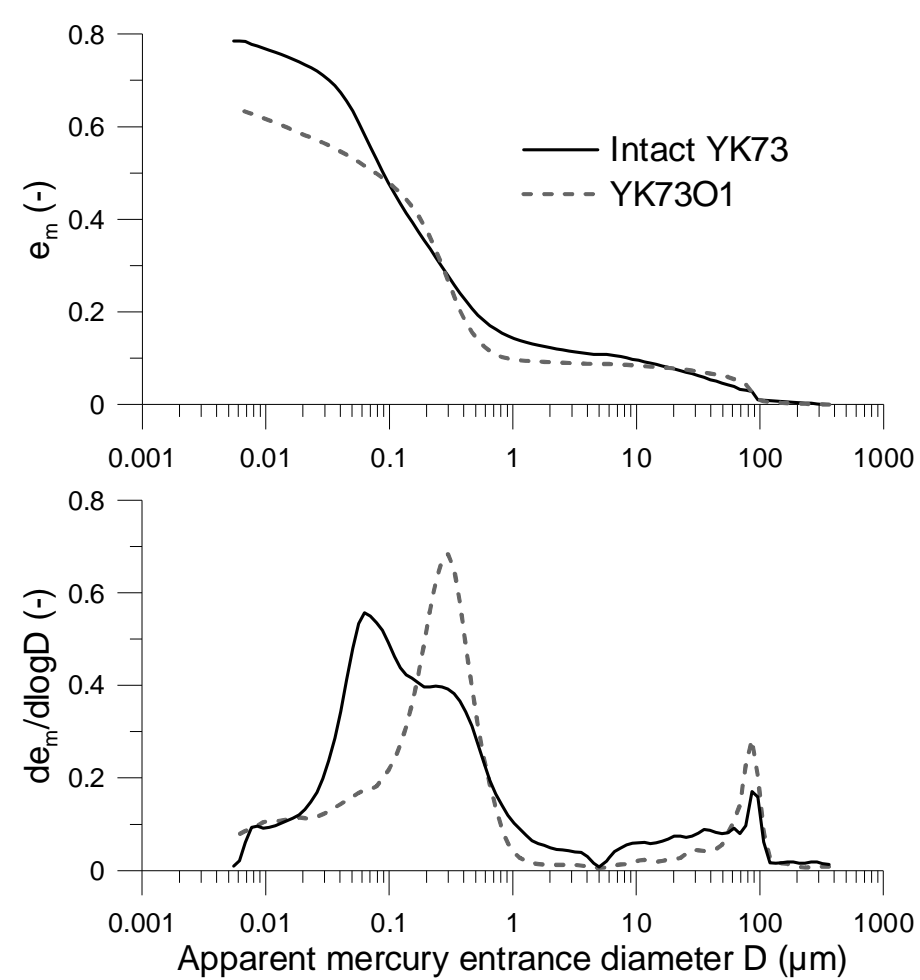
YK43, $125 \times 100 \mu \mathrm{m}$

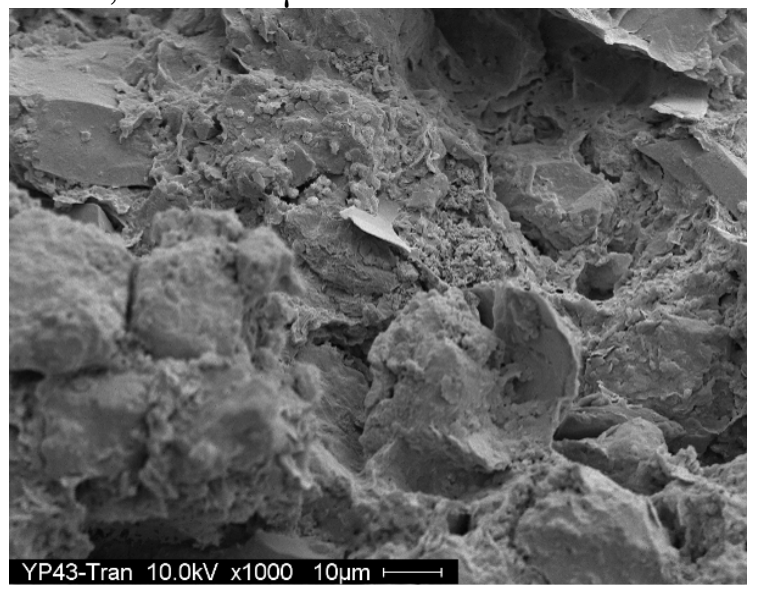

YK43, 25×20 $\mu \mathrm{m}$

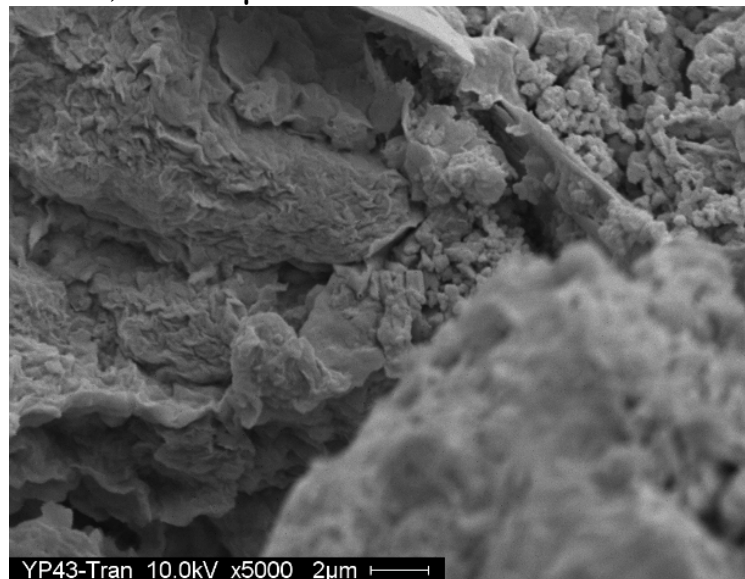

Figure 22: SEM on intact (left) and after LPO test (right) YK43

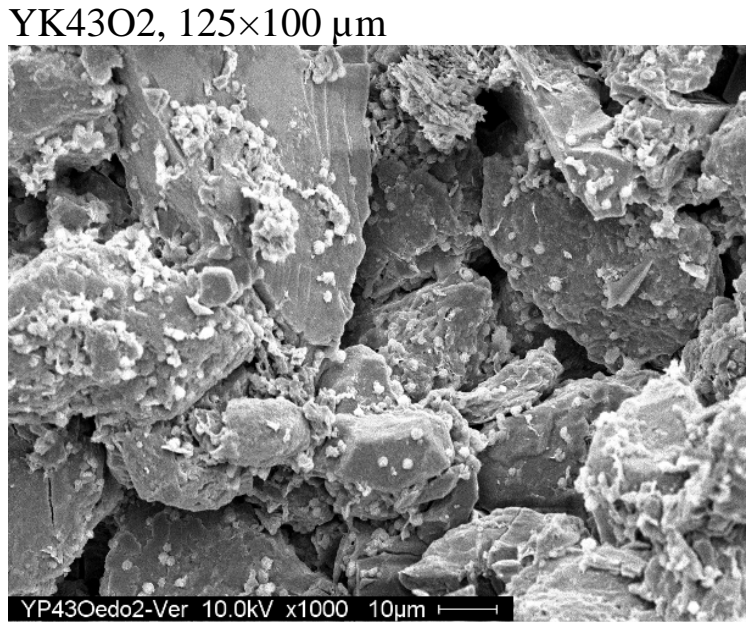

$\mathrm{YK} 43 \mathrm{O} 2,25 \times 20 \mu \mathrm{m}$

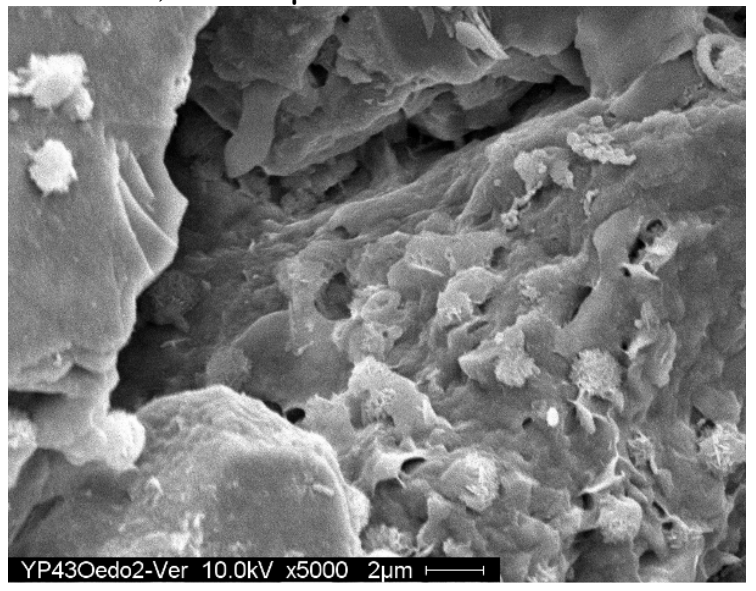

784

785

786 